\title{
Switching towards coal or renewable energy? The effects of financial capital on energy transitions
}

Rohan Best

Australian National University

February 2017

\begin{abstract}
Does a country's stock of financial capital affect its ability to achieve energy transitions? This paper uses data for up to 137 countries for the period 1998-2013 to investigate the importance of financial capital for changes in the use of each energy type. I find that financial capital supports transition to more capital-intensive energy types. For high-income countries, financial capital facilitates transitions from fossil fuels to modern renewable energy sources, especially wind. Both private credit from banks and domestic private debt securities support greater shares of wind energy. For lower-income countries, financial capital supports progression from biomass towards fossil fuel energy sources such as coal. I also find that countries with larger stocks of financial capital are more likely to move to more capitalintensive electricity generation systems.
\end{abstract}

Keywords: Energy; Financial capital (JEL O11, O13, Q42, Q43) 


\section{Introduction}

In this paper I use national data to examine the influence of different types of financial capital on consumption of different types of energy: biofuels and waste; hydro; coal; oil; natural gas; nuclear; wind; solar; and geothermal. In addition to analysis for a world sample, I present separate assessments for high-income and lower-income countries to reveal differences in the effect of financial capital on energy transitions according to development level. The impacts of financial capital on energy mix have a number of indirect but important implications. These relate to economic outcomes, environmental impacts including global climate change, and health outcomes affected by local air pollution.

I first define some key variables. Financial capital is the stock of financial assets that can be used to fund future production, and includes institutional assets such as bank deposits, and capital market instruments such as bonds and equity. Two key financial capital variables are (a) bank credit to the private sector and (b) outstanding private debt securities. Capital intensity is the capital cost to produce the same amount of electricity as one kilowatt of capacity operating on a continual basis (Timmons et al., 2014). ${ }^{1}$

Capital intensity differs considerably across energy types. Figure 1 shows the different capital intensities for electricity generation sources in the United States (US). The capital intensity is lowest for natural gas and coal, and is substantially higher for renewable energy sources such as wind and solar. Most of the costs of wind and solar energy are capital costs. For natural gas and coal, fuel costs are more important than capital costs. ${ }^{2}$

\footnotetext{
${ }^{1}$ More specifically, capital intensity is the capital cost per kilowatt, divided by the capacity factor. Capital costs are upfront costs in 2012 US dollars. The capacity factor is the ratio of actual output to potential capacity. Capital intensity is not the capital share of total costs.

2 The higher capital intensities for wind and solar also partly relate to the lower assumed average capacity factors for these energy types.
} 


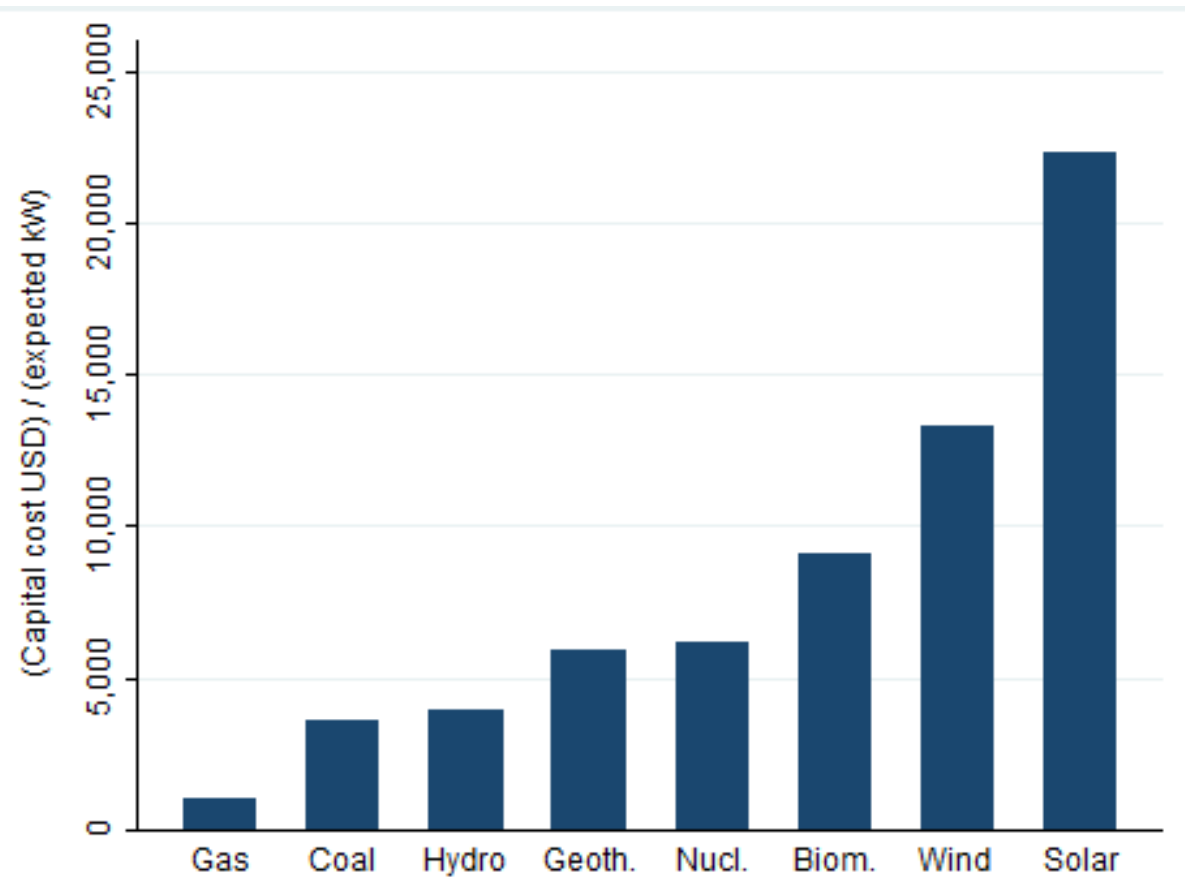

Fig.1. Capital intensity by electricity type (capital cost divided by expected kilowatts, calculated as capital cost per kilowatt (US EIA 2015a) divided by assumed capacity factor (US EIA 2015b)). Oil is not included. Sources: US EIA (2015a; 2015b), Timmons et al. (2014), author calculations.

The results of previous studies that have investigated the influence of financial capital on national-level energy use have varied. Brunnschweiler (2010) shows a positive impact of the financial sector on renewable energy production in developing countries. In contrast, Pfeiffer and Mulder (2013) find no evidence of an impact of finance on renewable energy adoption, rather than use, based on a variable measuring the importance of commercial banks relative to central banks in developing countries. For aggregate energy, Sadorsky (2010) finds that stock market development contributes to energy consumption in emerging economies. In a group of central and eastern European countries, the bank sector has been found to be important for explaining national energy consumption (Sadorsky, 2011). In contrast to other studies, I focus on the impacts of financial capital on nine energy types rather than more aggregated energy variables. This identifies the impacts of financial capital on energy mix transitions.

There are a number of other factors in addition to financial capital in determining energy mix. Larger endowments of energy resources are associated with greater domestic consumption of those energy types and lower use of substitute energy types. Also, countries have been shown to move up a national-level energy ladder as their gross domestic product per capita 
increases, progressing to fossil fuels then modern renewables (Burke, 2013). Climate is also likely to encourage the use of particular energy types. For instance, hydro energy is more feasible when there is more water available from greater precipitation, and less evaporation from lower temperatures.

The differing impacts of financial capital on energy transitions could have a number of economic implications. Energy is a necessary factor of production (Stern, 2011), with the type and cost of energy affecting the amount of resources available for other productive uses. Also, reliability of energy supply is an issue, depending on the types and sources of energy. Nations that rely on large amounts of imported fossil fuels may have to contend with energy security concerns, while intermittent renewable sources present reliability concerns in the absence of cost-effective energy storage.

There are also environmental implications of the mix of energy types used by national economies. At a local level, transition away from biomass energy could have favourable impacts on indoor air pollution, reducing adverse health impacts. Air pollution can also be exacerbated by greater use of energy sources such as coal. At a global level, greater use of fossil fuels contributes to greater risk of adverse climate changes. If financial capital facilitates the transition of lower-income countries towards fossil fuels, financial capital accumulation could play a role in the economic processes contributing to adverse climate change.

In section 2 of this paper, I discuss the mechanisms through which financial system size and structure may be important for national-level energy mixes. Section 3 details the method and data. I present the results in Section 4, and conclude in Section 5.

\section{The relationship between financial systems and energy types}

Capital-intensive energy production of all types can benefit from larger supplies of financial capital at lower cost. When there is a larger supply of aggregate financial capital available, greater competition between capital providers helps to lower the cost of capital. This lower cost of capital benefits all borrowers in an economy, with the largest benefits accruing to capital-intensive sectors that are more sensitive to cost of capital changes, including energy producers. If there is instead a shortage of financial capital, some energy projects may no longer be commercially viable, due to the elevated cost of capital (IEA, 2014). 
There are a number of financial segments that could be important for energy transitions. The banking sector has been the main source of external finance for energy investments in most countries, with capital markets offering another alternative (IEA, 2014). For instance, Corsatea et al. (2014) note the importance of corporate debt for wind energy development. While larger banking and capital market financial segments could support energy financing, aversion to higher-risk investments can relate to regulatory standards for some investors. The Basel III capital adequacy standards may increase the cost of long-term energy financing through banks (IEA, 2014), while the Solvency II standards discourage insurance company investments in securitized assets (Citi, 2015). For pension funds, low risk investments may also be preferred, hindering investment in higher-risk energy types.

Access to external finance has been found to be associated with greater innovation (Ayyagari et al., 2011) and financial innovation can be beneficial for some energy types. Financial innovation to produce different types of financial fund structures can produce different riskreturn profiles related to varying claims on income and capital, including more liquid and divisible investments. For instance, YieldCos are investment fund structures that own infrastructure assets and distribute dividends based on electricity revenue (OECD, 2015). As a portfolio of publicly listed energy assets, YieldCos require parent companies to have large amounts of capital, which is more likely in larger financial systems. Larger markets allow greater liquidity and more research analysis, underlying growth of YieldCos and the renewable energy generation that they finance.

Financial capital constraints can impede industrial expansion (Levine, 2005), including in the energy sector, and these constraints may relate to factors other than just the cost of capital. For instance, capital quantity can be restricted when bond covenants or loan tenor are not appropriate for energy producers. This is important for all energy types, as energy production is more reliant on external finance than many other industries (Rajan and Zingales, 1998).

Financial capital is typically in shorter supply in developing countries. International financial institutions and donors have consequently supported numerous financing initiatives for renewable energy in developing countries (Painuly and Wohlgemuth, 2006). Energy producers may have greater access to financial capital in developed countries, but this can vary over time. Following the global credit crunch beginning in 2008, there was less capital available for renewable energy, due to capital provider bankruptcies and higher risk aversion (NREL, 2011). 
Energy producers can potentially benefit from access to capital from both domestic and international sources. Investors have a home bias (Obstfeld and Rogoff, 2001), related to many possible reasons such as barriers to international investment, information asymmetries, and behavioural biases (Warren, 2010), meaning that domestic capital could be important in supporting domestic energy transitions. In addition, smaller scale energy projects, including some solar photovoltaic projects, may be too small to access international capital sources (Ondraczek et al., 2015). International capital flows might also be important for some energy producers, and access to international markets and international networks for bank syndicate lending can expand available private capital sources. Aid from international development agencies and bilateral government donations has also been a source of energy capital (Tirpak and Adams, 2008), but private capital might be increasingly important as financial sectors develop.

Financial capital constraints for energy producers could be overcome through access to either public or private sources of finance, and this varies by energy type. Nuclear energy relies more on public than private financial sources (Helm, 2012, p. 136). Nuclear presents a different set of risks to other energy types and can dissuade private investment. There are risks related to nuclear waste, in addition to the long-term and capital intensive nature of nuclear energy investment. Nuclear risks are also hard for private capital sources to diversify. Geothermal energy development can also be reliant on public finance due to the combination of resource risk, high capital intensity, and long lead times (ESMAP, 2012).

\section{Data and Method}

I estimate Eq. (1):

$$
\Delta^{2003-2013} S_{j, c}=F_{c}^{2003} \alpha_{j}+x_{c}^{\prime 2003} \chi_{j}+\varepsilon_{j, c}
$$

where $\Delta^{2003-2013} S_{j, c}$ is the change in the share of total primary energy supply for energy type $j$ in country $c$ over the ten-year period 2003-2013. $F$ is the financial capital variable: private credit from deposit money banks divided by GDP. $\boldsymbol{x}$ is a vector of other potential determinants of energy consumption. The error term is $\varepsilon_{j, c}$, with $E\left(\varepsilon_{j, c}\right)=0$.

My regressions for the change in energy share for the ten years to 2013 use ordinary least squares estimates with standard errors that are robust to heteroscedasticity. As the same set of 
independent variables is in each regression for Eq. (1), seemingly unrelated regression estimation provides no advantage over equation-by-equation ordinary least squares.

In addition to the energy shares, I also use electricity shares as well as an aggregate measure of capital intensity of electricity generation. ${ }^{3}$ I calculate the capital intensity measure as the product of capital intensity for each electricity type from Figure 1 and the share of total electricity output for each electricity type in each country, summed over all electricity types. ${ }^{4}$ This assumes that the capital intensities for electricity types in Figure 1, based on data from the US Energy Information Administration (US EIA) (2015a; 2015b), are representative for every country. As a robustness test, I also calculate capital intensity for each electricity type in each country, using the regional or country data from the IEA (2014) on capital costs in nine different countries or regions: Europe, United States, Japan, Russia, China, India, Middle East, Africa, and Brazil. ${ }^{5}$ The US EIA data do not cover the capital cost of electricity generation using oil. I proxy this using the US EIA capital intensity of natural gas multiplied by the oil:natural gas capital cost of electricity generation ratio in Japan (Power Generation Costs Analysis Working Group, 2015).

In addition to analysis of the full sample of up to 137 countries, I also consider two subsamples. This is to test for different impacts of financial capital on energy transitions for countries at different stages of development. I use World Bank (2016) income classifications, combining low-income countries with middle-income countries in one group. I refer to these countries as lower-income countries. The other group is high-income countries.

My next step is to use Eq. (2) in a fixed-effects panel setting:

$$
S_{j, c, t}=\boldsymbol{F}_{c, t}^{\prime} \boldsymbol{\alpha}_{j}+\boldsymbol{x}_{c, t}^{\prime} \chi_{j}+\varepsilon_{j, c, t}
$$

where $S_{j, c, t}$ is the share of total primary energy supply for energy type $j$ in country $c$ and year $t$. The dependent variable in Eq. (2) is in level terms. $\boldsymbol{F}$ is a vector of financial capital variables, with additional financial variables compared to Eq. (1). These are not used in Eq. (1) as the number of countries with data for each variable in both 2003 and 2013 is small. $\boldsymbol{x}$ is a vector of other determinants. Time effects are included, and the error term is $\varepsilon_{j, c, t}$, with $E\left(\varepsilon_{j, c, t}\right)=0$. The fixed-effects panel estimates are for 1998-2012.

\footnotetext{
${ }^{3}$ I thank an anonymous reviewer for the suggestion to use capital intensity as a dependent variable.

${ }^{4}$ The unit for the capital intensity measure is 2012 US dollars divided by expected kilowatts, then divided by one thousand.

${ }^{5}$ Regression results using IEA (2014) capital costs are in Table A1 in Appendix A.
} 
Primary energy supply data are taken from the International Energy Agency (IEA, 2015). For the dependent variables, I divide energy supply for each energy type by total primary energy supply. Energy supply is for nine different energy types: biofuels and waste, hydro, coal, oil, natural gas, nuclear, wind, solar, and geothermal. ${ }^{6}$ These make up 99.9 percent of total primary energy supply in 2013. Energy share data are summarized in Table 1.

\section{Table 1}

Energy-type share of total primary energy supply, by income grouping, 2013 (percent).

\begin{tabular}{|c|c|c|c|c|c|c|c|c|c|}
\hline & $\begin{array}{r}\text { Biofuels } \\
\text { and } \\
\text { waste }\end{array}$ & Hydro & Coal & Oil & $\begin{array}{r}\text { Natural } \\
\text { gas }\end{array}$ & Nuclear & Wind & Solar & $\begin{array}{r}\text { Geother } \\
\text { mal }\end{array}$ \\
\hline Lower-income & 15.2 & 2.7 & 41.9 & 24.1 & 13.7 & 1.2 & 0.3 & 0.3 & 0.6 \\
\hline High-income & 4.7 & 2.2 & 17.3 & 34.4 & 31.2 & 8.8 & 0.6 & 0.3 & 0.4 \\
\hline World & 10.0 & 2.5 & 29.9 & 29.1 & 22.2 & 4.9 & 0.4 & 0.3 & 0.5 \\
\hline
\end{tabular}

Notes: These statistics cover 137 countries. Source: IEA (2015).

The financial variables are from the Global Financial Development Database (GFDD, 2015) with key variables being bank credit to the private sector and outstanding private debt securities. The variable for private sector credit from deposit money banks, divided by GDP, has been used frequently in the empirical literature on the role of private financial institutions in economic outcomes (Čihák et al., 2012). This variable measures banking sector depth, representing private rather than public sources of capital, and is available for a broad group of countries. In addition to financial institutions, financial markets are also possible sources of finance. For the panel regressions, I use outstanding debt securities and stock market capitalization to represent financial market depth. To assess the impact of aggregate private credit and debt, I add three variables to form a composite private debt and credit variable. The three variables are private sector credit from deposit money banks, outstanding domestic private debt securities, and outstanding international private debt securities. Also, I use an aggregate public debt variable, made up of outstanding domestic public debt securities and outstanding international public debt securities. Each financial variable is divided by GDP. Table 2 shows that there is substantial variation in financial variables between different countries, with the standard deviation for each variable of a similar magnitude to the mean.

\footnotetext{
${ }^{6}$ Using IEA categories, the coal variable includes coal, peat, and oilshale. Oil includes crude, natural gas liquids and feedstocks, and oil products.
} 


\section{Table 2}

Financial variables, 1998-2012.

\begin{tabular}{lrrrr}
\hline Variable & Minimum & Mean & Maximum & $\begin{array}{r}\text { Standard } \\
\text { Deviation }\end{array}$ \\
\hline Private credit & 0.13 & 0.87 & 2.73 & 0.50 \\
Domestic private debt & 0.00 & 0.30 & 1.63 & 0.30 \\
International private debt & 0.00 & 0.28 & 3.64 & 0.45 \\
Private debt and credit & 0.15 & 1.44 & 6.85 & 1.03 \\
Public debt & 0.03 & 0.41 & 1.89 & 0.27 \\
Equity & 0.05 & 0.76 & 5.70 & 0.67 \\
\hline
\end{tabular}

Notes: Each variable is divided by GDP. Source: GFDD (2015). There are 551 observations.

I show some examples of positive relationships between financial capital and energy types in Figure 2 and Figure 3. For high-income countries, Figure 2 shows a positive relationship between domestic private debt and the wind share of energy supply. For lower-income countries, a positive relationship between private credit and coal share of energy is evident in Figure 3. These scatter plots give an indication of the relationship between financial capital and energy types without controlling for other variables.

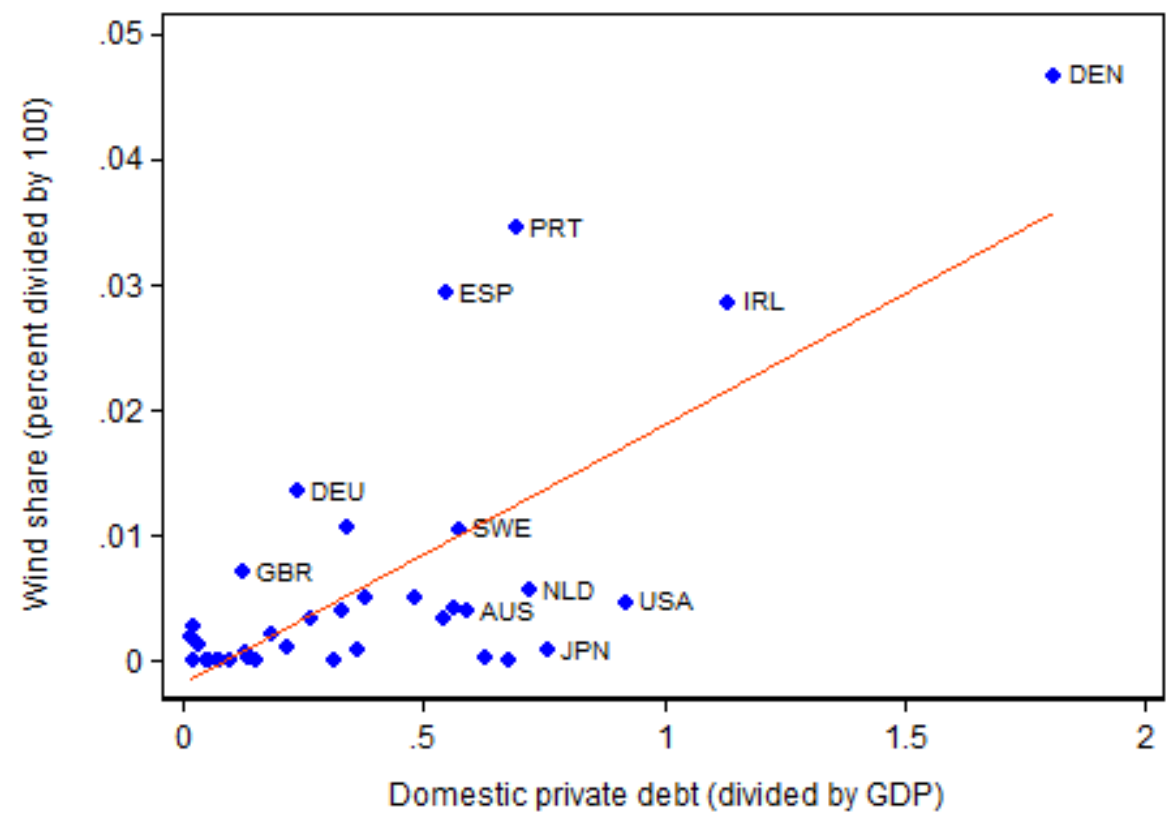

Fig. 2. Outstanding domestic private debt securities divided by GDP versus wind share of total primary energy supply (percent divided by 100). 36 countries are included for 2011, based on data availability for high-income countries. Sources: IEA (2015), GFDD (2015). 


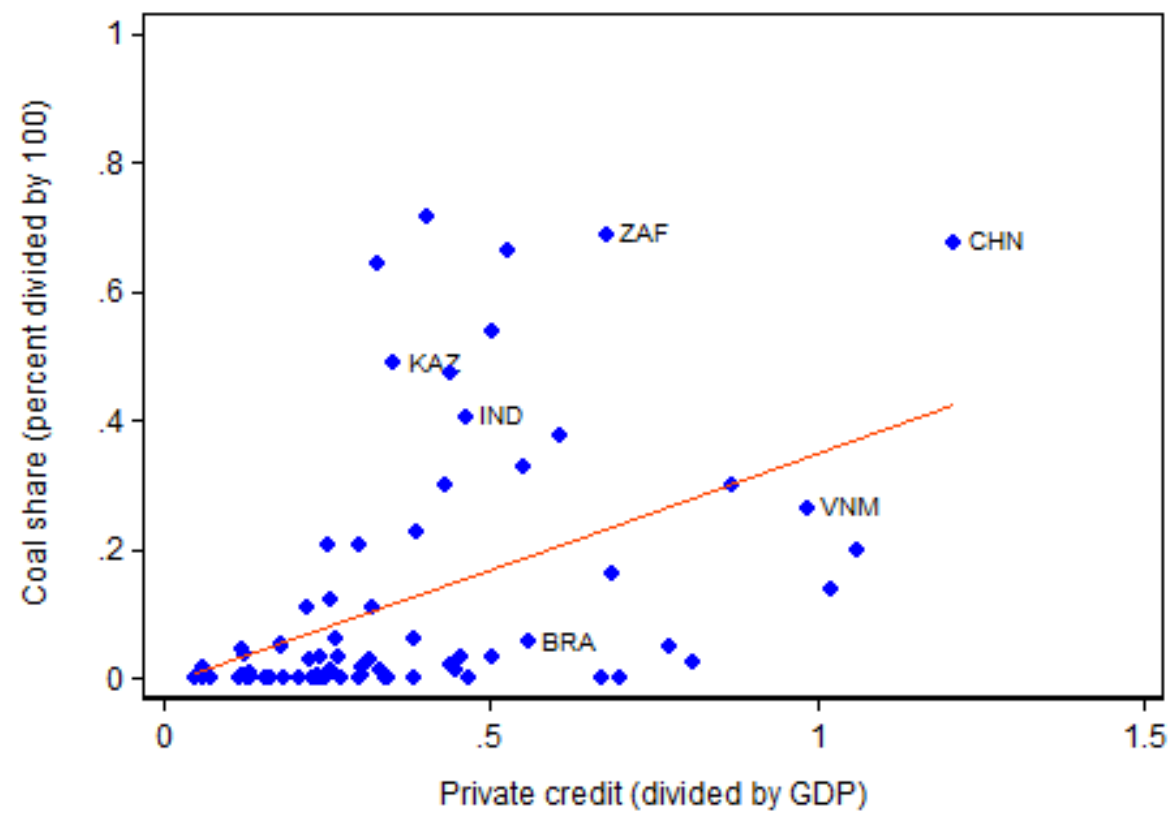

Fig.3. Bank credit to the private sector divided by GDP versus coal share of total primary energy supply (percent divided by 100). 74 lower-income countries are included for 2011, based on data availability. Sources: IEA (2015), GFDD (2015).

Other potential determinants of changes in energy-type use include the log of GDP per capita, fossil fuel reserves per capita, forest area per capita, land area per capita, average precipitation and temperature, initial total energy consumption per capita, and the percentage change in total energy consumption per capita over the previous five years. Prior research has found that some of these variables are important for the energy/electricity mix (Burke, 2010; Burke, 2013). Initial energy use may impact future energy use because energy production depends on long-lived infrastructure. The growth rate of previous energy use can also impact on future energy use through the impact on predicted energy demand (Popp et al., 2011) and energy investment decisions, and has been found to impact on energy types such as hydro (Pfeiffer and Mulder, 2013). The independent variables are initial values from the start of the ten-year period, with some exceptions: precipitation and temperature are ten-year averages up to 2013 to measure climate rather than weather, coal reserves are only available for 2011 , and the five-year percentage change in energy consumption is for the five years to 2003.

In addition to the key data sources for energy (IEA, 2015) and finance (GFDD, 2015), I also use some further sources. Fossil fuel reserves are from the United States Energy Information 
Administration (US EIA, 2015c). Fossil fuel reserves are for coal, oil, and natural gas. ${ }^{7}$ I use GDP per capita, ${ }^{8}$ total population, ${ }^{9}$ land area, and forest area data from the World

Development Indicators (World Bank, 2016). Precipitation and temperature data are from CRU CY v.3.22 dataset (Harris et al., 2014).

To reduce possible reverse causation, I model changes in the energy mix shares against initial values of the financial capital variable. Using an initial value is also suitable because financial capital may take time to affect energy production and consumption, due to long lead times in energy investment. Reverse causation from energy types to financial segments is unlikely for modern energy types, such as wind and solar, which are small components of national energy mixes (as shown in Table 1). In contrast, financial stocks are often large and have built up over time, with the large size in relation to GDP evident in Table 2. The impact of other energy types on financial development would also generally be outweighed by other non-energy sectors, because the finance sector is used by all sectors of the economy and not just the energy sector or just one specific energy type.

Omitted variable bias could potentially arise from the absence of a policy variable. While policy variables are important for renewable energy (Zhao et al., 2013), policy support and financial sector size are unlikely to be highly correlated. This relates to financial sectors servicing entire economies rather than just the energy sector, or just single energy types. The omission of a policy variable in this paper thus might not be a major source of bias for the coefficients for the financial sector variables.

To further address potential endogeneity, Eq. (2) uses panel data for the dependent variable in levels. Inclusion of time dummies helps to account for globally-common omitted variables, such as changes over time in global energy prices or technology. Advances in technology have been found to have a small effect in raising investment in some renewable energy types in OECD countries (Popp et al., 2011). Country-specific factors, such as time-invariant aspects of institutions or policies, are also accounted for in the fixed-effects model.

Reverse causation for the panel estimation from Eq. (2) could arise in a few special cases, when an energy type has a causal impact on a particular financial market segment. For example, development of geothermal or hydro energy could lead to larger international

\footnotetext{
${ }^{7}$ I use BP (2015) conversion factors to convert oil and gas into thousand tonnes of oil equivalent, and a US EIA (2015c) conversion factor to convert coal into thousand tonnes of oil equivalent.

${ }^{8}$ Purchasing power parity (constant 2011 international dollars).

${ }^{9}$ I use population data to convert variables into per capita values.
} 
private debt borrowing, as the combination of high capital intensity, long time horizons, and geological risk factors discourages capital providers in some countries. In response to this, I use a composite financial variable for debt and credit that includes domestic and international market debt in addition to domestic bank credit to the private sector. Reverse causation is less likely for an aggregated variable that includes both bank credit and market debt.

\section{Results}

Table 3 shows results for Eq. (1) for each of the nine energy types for the full sample of countries. The financial variable, bank credit to the private sector divided by GDP, has positive and statistically significant impacts on two of the nine energy types. Wind and solar energy both have positive coefficients that are statistically significant at the one percent level, indicating that these capital-intensive energy types benefit from greater supplies of financial capital. ${ }^{10}$

In the oil regression, the coefficient for private credit is negative and statistically significant at the ten percent level. This suggests that greater supplies of financial capital could encourage reductions in use of energy types with lower capital intensity, such as some fossil fuels. More efficient use of oil through technological innovation is one possible contributor to the negative relationship between financial capital and oil share. For instance, greater access to finance can support improvements in fuel economy through innovative automobile design, such as for new passenger light-duty vehicles (IEA, 2012). Road transport energy use is a large and growing component of final oil consumption (Gao et al., 2015), and is likely a factor in explaining the negative coefficient.

The variables in Table 3 explain 34 percent of the cross-country variation in the change of wind share and 37 percent for the solar share over the period 2003-2013. ${ }^{11}$ The coefficients of determination for some of the other energy types are also quite high. An exception is nuclear energy, with only two percent of variation explained by the financial and other variables in the model. This is reasonable given that most nuclear capacity was added prior to

\footnotetext{
${ }^{10}$ I find consistent results for the private credit variable using dependent variables representing the (a) change in per capita energy consumption in tonnes of oil equivalent, or (b) level of primary energy supply share (rather than the change). Other robustness tests also produce similar results for the wind regression, including dependent variables for the ten-year period to 2012 instead of 2013, the five-year period to 2013 instead of the ten-year period to 2013, and non-linear estimators including fractional logit and Poisson models.

${ }^{11}$ Other variables that could impact energy supply include foreign direct investment and gross capital formation. These variables are not statistically significant when used to replace the financial capital variable.
} 
the ten-year period to 2013 and that nuclear energy relies more on public rather than private capital.

The economic significance of financial capital for wind energy consumption is considerable. A one standard deviation increase in private credit by deposit money banks as a share of GDP leads to an increase of 0.5 of one standard deviation for the change in wind share of total primary energy supply, all else equal. Expressed differently, a one percentage point increase in private credit by deposit money banks as a share of GDP is associated with a 0.008 percentage point increase in wind energy share. For oil, a one percentage point increase in the private credit variable is associated with a 0.033 percentage point decrease in oil energy share. 
Table 3. Results, change in share of total primary energy supply for the ten years to 2013.

\begin{tabular}{|c|c|c|c|c|c|c|c|c|c|}
\hline & \multicolumn{9}{|c|}{ Dependent variables: Ten-year change in share of total primary energy supply } \\
\hline & $\begin{array}{r}\text { Biofuels } \\
\text { and waste }\end{array}$ & Hydro & Coal & Oil & $\begin{array}{r}\text { Natural } \\
\text { Gas }\end{array}$ & Nuclear & Wind & Solar & $\begin{array}{r}\text { Geo- } \\
\text { thermal }\end{array}$ \\
\hline $\begin{array}{l}\text { Private credit, } \\
\text { divided by GDP }\end{array}$ & $\begin{array}{c}-0.012 \\
(0.012)\end{array}$ & $\begin{array}{r}0.003 \\
(0.005)\end{array}$ & $\begin{array}{r}0.017 \\
(0.012)\end{array}$ & $\begin{array}{l}-0.033^{*} \\
(0.018)\end{array}$ & $\begin{array}{r}0.005 \\
(0.017)\end{array}$ & $\begin{array}{r}0.009 \\
(0.020)\end{array}$ & $\begin{array}{r}0.008 * * * \\
(0.003)\end{array}$ & $\begin{array}{r}0.004 * * * \\
(0.002)\end{array}$ & $\begin{array}{r}0.007 \\
(0.005)\end{array}$ \\
\hline Log GDP per capita & $\begin{array}{r}0.023 * * * \\
(0.007)\end{array}$ & $\begin{array}{r}0.000 \\
(0.003)\end{array}$ & $\begin{array}{l}-0.007^{*} \\
(0.004)\end{array}$ & $\begin{array}{r}-0.023 * * * \\
(0.008)\end{array}$ & $\begin{array}{r}0.012 \\
(0.007)\end{array}$ & $\begin{array}{l}-0.005 \\
(0.006)\end{array}$ & $\begin{array}{r}0.001^{* * * *} \\
(0.000)\end{array}$ & $\begin{array}{r}0.001 * * * \\
(0.000)\end{array}$ & $\begin{array}{l}-0.004 \\
(0.003)\end{array}$ \\
\hline $\begin{array}{l}\text { Coal reserves, } \\
\text { KTOE per capita }\end{array}$ & $\begin{array}{l}-0.001 \\
(0.009)\end{array}$ & $\begin{array}{l}0.006^{*} \\
(0.003)\end{array}$ & $\begin{array}{r}-0.028^{* *} \\
(0.011)\end{array}$ & $\begin{array}{r}0.008 \\
(0.014)\end{array}$ & $\begin{array}{r}0.025 \\
(0.022)\end{array}$ & $\begin{array}{r}0.006 \\
(0.010)\end{array}$ & $\begin{array}{r}0.000 \\
(0.001)\end{array}$ & $\begin{array}{r}0.001 * * \\
(0.001)\end{array}$ & $\begin{array}{l}-0.011 \\
(0.007)\end{array}$ \\
\hline $\begin{array}{l}\text { Oil reserves, } \\
\text { KTOE per capita }\end{array}$ & $\begin{array}{r}-0.006 \\
(0.005)\end{array}$ & $\begin{array}{r}-0.001 \\
(0.003)\end{array}$ & $\begin{array}{r}0.013 * * * \\
(0.004)\end{array}$ & $\begin{array}{l}-0.002 \\
(0.008)\end{array}$ & $\begin{array}{r}-0.001 \\
(0.007)\end{array}$ & $\begin{array}{r}0.000 \\
(0.002)\end{array}$ & $\begin{array}{r}-0.000 \\
(0.001)\end{array}$ & $\begin{array}{r}-0.001^{* * *} \\
(0.000)\end{array}$ & $\begin{array}{r}-0.001 \\
(0.002)\end{array}$ \\
\hline $\begin{array}{l}\text { Gas reserves, } \\
\text { KTOE per capita }\end{array}$ & $\begin{array}{l}-0.002 \\
(0.003)\end{array}$ & $\begin{array}{l}-0.001 \\
(0.002)\end{array}$ & $\begin{array}{r}0.006 * * * \\
(0.002)\end{array}$ & $\begin{array}{r}-0.009 * * \\
(0.004)\end{array}$ & $\begin{array}{l}0.006^{*} \\
(0.003)\end{array}$ & $\begin{array}{r}-0.001 \\
(0.001)\end{array}$ & $\begin{array}{r}0.000 \\
(0.000)\end{array}$ & $\begin{array}{r}0.000 \\
(0.000)\end{array}$ & $\begin{array}{r}-0.001 \\
(0.001)\end{array}$ \\
\hline $\begin{array}{l}\text { Forest area, sq. km, } \\
\text { per capita }\end{array}$ & $\begin{array}{r}-0.342 * * \\
(0.157)\end{array}$ & $\begin{array}{r}0.141 \\
(0.115)\end{array}$ & $\begin{array}{l}-0.215^{*} \\
(0.116)\end{array}$ & $\begin{array}{r}0.179 \\
(0.241)\end{array}$ & $\begin{array}{r}0.419^{* *} \\
(0.204)\end{array}$ & $\begin{array}{r}0.140 \\
(0.091)\end{array}$ & $\begin{array}{r}0.006 \\
(0.012)\end{array}$ & $\begin{array}{r}0.007 \\
(0.008)\end{array}$ & $\begin{array}{r}-0.240 \\
(0.151)\end{array}$ \\
\hline $\begin{array}{l}\text { Land area sq. km, } \\
\text { per capita }\end{array}$ & $\begin{array}{r}-0.088^{* *} \\
(0.040)\end{array}$ & $\begin{array}{r}-0.072 * * \\
(0.030)\end{array}$ & $\begin{array}{r}0.052 \\
(0.032)\end{array}$ & $\begin{array}{r}0.061 \\
(0.096)\end{array}$ & $\begin{array}{l}-0.111 \\
(0.076)\end{array}$ & $\begin{array}{r}-0.001 \\
(0.017)\end{array}$ & $\begin{array}{r}-0.013^{* * *} \\
(0.005)\end{array}$ & $\begin{array}{r}-0.012 * * * \\
(0.004)\end{array}$ & $\begin{array}{l}0.118^{*} \\
(0.068)\end{array}$ \\
\hline $\begin{array}{l}\text { Temperature, }{ }^{\circ} \mathrm{C} \\
\text { ten-year average }\end{array}$ & $\begin{array}{r}-0.002 * * \\
(0.001)\end{array}$ & $\begin{array}{r}0.000 \\
(0.000)\end{array}$ & $\begin{array}{l}-0.001 \\
(0.001)\end{array}$ & $\begin{array}{l}-0.001 \\
(0.001)\end{array}$ & $\begin{array}{r}0.002 * * \\
(0.001)\end{array}$ & $\begin{array}{r}0.001 \\
(0.001)\end{array}$ & $\begin{array}{r}-0.000 \\
(0.000)\end{array}$ & $\begin{array}{r}0.000^{* *} \\
(0.000)\end{array}$ & $\begin{array}{r}-0.000 \\
(0.000)\end{array}$ \\
\hline $\begin{array}{l}\text { Precipitation, meters } \\
\text { ten-year average }\end{array}$ & $\begin{array}{l}-0.003 \\
(0.007)\end{array}$ & $\begin{array}{r}-0.000 \\
(0.003)\end{array}$ & $\begin{array}{r}0.020 * * * \\
(0.006)\end{array}$ & $\begin{array}{l}-0.011 \\
(0.009)\end{array}$ & $\begin{array}{l}-0.009 \\
(0.009)\end{array}$ & $\begin{array}{r}-0.003 \\
(0.002)\end{array}$ & $\begin{array}{l}-0.001 \\
(0.001)\end{array}$ & $\begin{array}{r}-0.002 * * * \\
(0.001)\end{array}$ & $\begin{array}{r}0.008 * * \\
(0.004)\end{array}$ \\
\hline $\begin{array}{l}\text { Initial energy use } \\
\text { per capita }\end{array}$ & $\begin{array}{r}0.000 \\
(0.003)\end{array}$ & $\begin{array}{r}0.001 \\
(0.002)\end{array}$ & $\begin{array}{r}-0.005^{* *} \\
(0.002)\end{array}$ & $\begin{array}{r}0.006 \\
(0.005)\end{array}$ & $\begin{array}{l}-0.003 \\
(0.004)\end{array}$ & $\begin{array}{r}0.001 \\
(0.001)\end{array}$ & $\begin{array}{l}-0.001^{*} \\
(0.000)\end{array}$ & $\begin{array}{r}-0.000^{* *} \\
(0.000)\end{array}$ & $\begin{array}{r}0.002 \\
(0.002)\end{array}$ \\
\hline $\begin{array}{l}\text { Change in total } \\
\text { energy use pc }\end{array}$ & $\begin{array}{l}-0.023 \\
(0.053)\end{array}$ & $\begin{array}{l}0.053^{*} \\
(0.028)\end{array}$ & $\begin{array}{r}0.060^{* *} \\
(0.026)\end{array}$ & $\begin{array}{r}-0.171 * * * \\
(0.045)\end{array}$ & $\begin{array}{r}0.063 \\
(0.040)\end{array}$ & $\begin{array}{r}0.011 \\
(0.011)\end{array}$ & $\begin{array}{l}-0.005 \\
(0.003)\end{array}$ & $\begin{array}{r}0.002 \\
(0.002)\end{array}$ & $\begin{array}{r}0.012 \\
(0.015)\end{array}$ \\
\hline $\mathrm{R}^{2}$ & 0.322 & 0.146 & 0.282 & 0.357 & 0.145 & 0.022 & 0.339 & 0.370 & 0.182 \\
\hline
\end{tabular}

Notes: ***,**, * show statistical significance at 1, 5 and 10 percent levels respectively. Robust standard errors are in brackets below the coefficients. All countries are included if data are available. The sample covers 114 countries for coal and solar regressions and 115 for other types. The independent variables are initial values; they are for the year 2003 unless otherwise noted. Coal reserves are for 2011. Temperature and precipitation are 10-year averages to 2013. Initial energy use is total primary energy supply per capita. Change in total energy use per capita is a percentage change for the five years to 2003. 
There are reasonable results for some of the natural endowment controls in Table 3. For example, countries with larger gas reserves experienced reductions in the share of oil energy consumed in Table 3, all else equal. This is an example of one energy type substituting for another energy type. Higher reserves of an energy type could also encourage higher use of another. For example, larger coal reserves are associated with greater changes in solar share in Table 3, possibly due to concerns over future pollution or carbon emissions. Renewable and non-renewable energy are substitutes in some industries but complements in others (Kumar et al. 2015). Larger gas reserves are also associated with larger increases in gas share, showing that countries increase their share of energy types when they have larger endowments. This relationship is not evident for the changes in other energy types with less rapid growth, but is evident if levels of energy types are used for the dependent variable rather than changes. ${ }^{12}$

Table 4 uses shares of electricity output instead of shares of total primary energy supply. There is again a positive and significant coefficient for private credit in the wind regression in Table 4. In the solar regression, the coefficient for private credit is again positive, but is not significant. There is a negative and significant coefficient for natural gas in Table 4. This is similar to Table 3 where there is also a negative and significant coefficient for a fossil fuel energy type, but the significant coefficient in Table 3 is for oil rather than natural gas. The importance of financial capital for more capital-intensive electricity systems is also evident in the final column of Table 4; there is a positive coefficient for private credit, significant at the one percent level, in explaining the change in the aggregate capital intensity measure. For a one percentage point increase in private credit divided by GDP, there is an increase in the change in the aggregate capital intensity of national electricity generation systems of eight US dollars per expected kilowatt.

\footnotetext{
${ }^{12}$ Results with dependent variables in levels rather than changes are included in Table A2 in Appendix A.
} 
Table 4. Results, change in electricity share and capital intensity for the ten years to 2013.

\begin{tabular}{|c|c|c|c|c|c|c|c|c|c|c|}
\hline & \multicolumn{10}{|c|}{ Dependent variables: Ten-year change in electricity share, and ten-year change in capital intensity } \\
\hline & $\begin{array}{r}\text { Biofuels } \\
\text { and waste }\end{array}$ & Hydro & Coal & Oil & $\begin{array}{r}\text { Natural } \\
\text { Gas }\end{array}$ & Nuclear & Wind & Solar & $\begin{array}{r}\text { Geo- } \\
\text { thermal }\end{array}$ & $\begin{array}{r}\text { Capital } \\
\text { Intensity }\end{array}$ \\
\hline $\begin{array}{l}\text { Private credit, } \\
\text { divided by GDP }\end{array}$ & $\begin{array}{r}0.005 \\
(0.007)\end{array}$ & $\begin{array}{l}-0.004 \\
(0.019)\end{array}$ & $\begin{array}{r}0.008 \\
(0.020)\end{array}$ & $\begin{array}{r}0.013 \\
(0.028)\end{array}$ & $\begin{array}{r}-0.086^{* * *} \\
(0.035)\end{array}$ & $\begin{array}{r}0.013 \\
(0.037)\end{array}$ & $\begin{array}{r}0.046^{* *} \\
(0.019)\end{array}$ & $\begin{array}{r}0.004 \\
(0.003)\end{array}$ & $\begin{array}{r}0.003 \\
(0.003)\end{array}$ & $\begin{array}{r}0.844 * * * \\
(0.251)\end{array}$ \\
\hline Log GDP per capita & $\begin{array}{r}0.006 * * * * \\
(0.002)\end{array}$ & $\begin{array}{r}0.011 \\
(0.017)\end{array}$ & $\begin{array}{l}-0.008 \\
(0.006)\end{array}$ & $\begin{array}{l}-0.024 \\
(0.017)\end{array}$ & $\begin{array}{r}0.019 \\
(0.014)\end{array}$ & $\begin{array}{l}-0.007 \\
(0.009)\end{array}$ & $\begin{array}{r}0.005 \\
(0.003)\end{array}$ & $\begin{array}{r}0.003 * * \\
(0.001)\end{array}$ & $\begin{array}{r}-0.005^{* *} \\
(0.002)\end{array}$ & $\begin{array}{r}0.068 \\
(0.067)\end{array}$ \\
\hline $\begin{array}{l}\text { Coal reserves, } \\
\text { KTOE per capita }\end{array}$ & $\begin{array}{r}-0.007 \\
(0.007)\end{array}$ & $\begin{array}{r}0.028 \\
(0.023)\end{array}$ & $\begin{array}{r}-0.007 \\
(0.031)\end{array}$ & $\begin{array}{r}0.021 \\
(0.027)\end{array}$ & $\begin{array}{l}-0.035 \\
(0.031)\end{array}$ & $\begin{array}{r}0.006 \\
(0.017)\end{array}$ & $\begin{array}{r}-0.002 \\
(0.007)\end{array}$ & $\begin{array}{l}0.005^{*} \\
(0.003)\end{array}$ & $\begin{array}{l}-0.010^{*} \\
(0.005)\end{array}$ & $\begin{array}{r}0.129 \\
(0.113)\end{array}$ \\
\hline $\begin{array}{l}\text { Oil reserves, } \\
\text { KTOE per capita }\end{array}$ & $\begin{array}{l}-0.001 \\
(0.003)\end{array}$ & $\begin{array}{r}0.004 \\
(0.009)\end{array}$ & $\begin{array}{r}0.020^{* * * *} \\
(0.006)\end{array}$ & $\begin{array}{r}-0.015 \\
(0.011)\end{array}$ & $\begin{array}{r}-0.008 \\
(0.014)\end{array}$ & $\begin{array}{r}0.003 \\
(0.005)\end{array}$ & $\begin{array}{r}-0.001 \\
(0.003)\end{array}$ & $\begin{array}{r}-0.003^{* * * *} \\
(0.001)\end{array}$ & $\begin{array}{l}-0.004^{*} \\
(0.002)\end{array}$ & $\begin{array}{r}-0.099 \\
(0.060)\end{array}$ \\
\hline $\begin{array}{l}\text { Gas reserves, } \\
\text { KTOE per capita }\end{array}$ & $\begin{array}{r}0.000 \\
(0.000)\end{array}$ & $\begin{array}{r}-0.000 \\
(0.001)\end{array}$ & $\begin{array}{r}0.003 * * * \\
(0.001)\end{array}$ & $\begin{array}{r}0.006 * * * \\
(0.002)\end{array}$ & $\begin{array}{r}-0.009 * * * \\
(0.003)\end{array}$ & $\begin{array}{r}0.000 \\
(0.001)\end{array}$ & $\begin{array}{r}0.000 \\
(0.001)\end{array}$ & $\begin{array}{r}-0.000 * * \\
(0.000)\end{array}$ & $\begin{array}{r}-0.000 \\
(0.000)\end{array}$ & $\begin{array}{r}0.016 \\
(0.012)\end{array}$ \\
\hline $\begin{array}{l}\text { Forest area, sq. km, } \\
\text { per capita }\end{array}$ & $\begin{array}{l}-0.068 \\
(0.076)\end{array}$ & $\begin{array}{r}-0.890 * * \\
(0.451)\end{array}$ & $\begin{array}{r}-0.665^{* * * *} \\
(0.229)\end{array}$ & $\begin{array}{r}0.886 \\
(0.555)\end{array}$ & $\begin{array}{r}0.798 \\
(0.561)\end{array}$ & $\begin{array}{r}0.173 \\
(0.173)\end{array}$ & $\begin{array}{l}-0.015 \\
(0.077)\end{array}$ & $\begin{array}{r}0.015 \\
(0.022)\end{array}$ & $\begin{array}{l}-0.188 \\
(0.126)\end{array}$ & $\begin{array}{r}-1.978 \\
(1.811)\end{array}$ \\
\hline $\begin{array}{l}\text { Land area sq. km, } \\
\text { per capita }\end{array}$ & $\begin{array}{r}-0.024 \\
(0.022)\end{array}$ & $\begin{array}{r}-0.061 \\
(0.148)\end{array}$ & $\begin{array}{r}0.199 * * \\
(0.078)\end{array}$ & $\begin{array}{l}-0.195 \\
(0.273)\end{array}$ & $\begin{array}{r}0.019 \\
(0.281)\end{array}$ & $\begin{array}{r}0.043 \\
(0.046)\end{array}$ & $\begin{array}{r}-0.058^{* *} \\
(0.026)\end{array}$ & $\begin{array}{r}-0.040 * * * \\
(0.014)\end{array}$ & $\begin{array}{l}0.079 * \\
(0.045)\end{array}$ & $\begin{array}{l}-1.590 * \\
(0.882)\end{array}$ \\
\hline $\begin{array}{l}\text { Temperature, }{ }^{\circ} \mathrm{C} \\
\text { ten-year average }\end{array}$ & $\begin{array}{r}-0.001^{* * * *} \\
(0.000)\end{array}$ & $\begin{array}{r}-0.002 \\
(0.001)\end{array}$ & $\begin{array}{r}-0.001 \\
(0.001)\end{array}$ & $\begin{array}{l}-0.001 \\
(0.002)\end{array}$ & $\begin{array}{r}0.004 * * \\
(0.002)\end{array}$ & $\begin{array}{r}0.001 \\
(0.001)\end{array}$ & $\begin{array}{l}-0.001^{*} \\
(0.000)\end{array}$ & $\begin{array}{r}0.000 \\
(0.000)\end{array}$ & $\begin{array}{r}0.000 \\
(0.000)\end{array}$ & $\begin{array}{l}-0.015^{*} \\
(0.008)\end{array}$ \\
\hline $\begin{array}{l}\text { Precipitation, meters } \\
\text { ten-year average }\end{array}$ & $\begin{array}{r}0.006 \\
(0.004)\end{array}$ & $\begin{array}{r}0.010 \\
(0.014)\end{array}$ & $\begin{array}{r}0.040 * * * \\
(0.010)\end{array}$ & $\begin{array}{l}-0.021 \\
(0.021)\end{array}$ & $\begin{array}{l}-0.033^{*} \\
(0.020)\end{array}$ & $\begin{array}{l}-0.004 \\
(0.004)\end{array}$ & $\begin{array}{l}-0.002 \\
(0.005)\end{array}$ & $\begin{array}{r}-0.003 * * * \\
(0.001)\end{array}$ & $\begin{array}{r}0.002 \\
(0.003)\end{array}$ & $\begin{array}{r}-0.021 \\
(0.093)\end{array}$ \\
\hline $\begin{array}{l}\text { Initial electricity use } \\
\text { per capita }\end{array}$ & $\begin{array}{l}-0.014 * \\
(0.008)\end{array}$ & $\begin{array}{r}0.008 \\
(0.042)\end{array}$ & $\begin{array}{l}-0.039 \\
(0.025)\end{array}$ & $\begin{array}{r}0.031 \\
(0.036)\end{array}$ & $\begin{array}{r}0.023 \\
(0.041)\end{array}$ & $\begin{array}{r}-0.000 \\
(0.015)\end{array}$ & $\begin{array}{r}-0.022 * * \\
(0.010)\end{array}$ & $\begin{array}{r}-0.000 \\
(0.003)\end{array}$ & $\begin{array}{r}0.023^{* *} \\
(0.011)\end{array}$ & $\begin{array}{r}-0.187 \\
(0.181)\end{array}$ \\
\hline $\begin{array}{l}\text { Change in total } \\
\text { electricity use pc }\end{array}$ & $\begin{array}{r}0.001 \\
(0.003)\end{array}$ & $\begin{array}{r}0.020 \\
(0.021)\end{array}$ & $\begin{array}{r}0.009^{* *} \\
(0.004)\end{array}$ & $\begin{array}{l}-0.011 \\
(0.025)\end{array}$ & $\begin{array}{r}-0.022^{* *} \\
(0.009)\end{array}$ & $\begin{array}{r}0.004 \\
(0.004)\end{array}$ & $\begin{array}{r}-0.005^{* *} \\
(0.002)\end{array}$ & $\begin{array}{r}0.004 * * * \\
(0.001)\end{array}$ & $\begin{array}{r}0.000 \\
(0.001)\end{array}$ & $\begin{array}{l}0.097^{*} \\
(0.059)\end{array}$ \\
\hline $\mathrm{R}^{2}$ & 0.197 & 0.084 & 0.237 & 0.078 & 0.151 & 0.030 & 0.282 & 0.280 & 0.269 & 0.365 \\
\hline
\end{tabular}

Notes: ***,**,* show statistical significance at 1,5 and 10 percent levels respectively. Robust standard errors are in brackets below the coefficients. All countries are included if data are available. The sample covers 113 countries for coal and solar regressions and 114 for other types. The independent variables are initial values; they are for the year 2003 unless otherwise noted. Coal reserves are for 2011. Temperature and precipitation are 10-year averages to 2013. Initial electricity use is total electricity output per capita. Change in total electricity use per capita is a percentage change for the five years to 2003. Capital intensity is a measure calculated by the author as electricity-type capital intensity multiplied by electricity share, summed for each type of electricity. 
Table 5 presents estimates for high-income countries. The financial capital coefficients for wind and solar energy are similar to Table 3 . The coefficient for private credit is significant at the five percent level for high-income countries in Table 5 for the wind regression, and at the ten percent level for the solar regression due to the higher standard error for the smaller sample. Private credit still has a negative relationship with oil energy for high-income countries, but is no longer significant.

Most of the other explanatory variables in Table 5 are not significant, but some significant coefficients match expectation. Land area has a positive coefficient for geothermal energy, significant at the one percent level, perhaps because more land provides more space for domestic geothermal sources. There are significant coefficients in the solar regression, including a positive coefficient for temperature and negative coefficient for precipitation. These are reasonable, as solar energy would benefit from greater solar irradiation with higher temperatures and less rainfall.

In Table 6, which has results for lower-income countries, there are key differences in financial capital impact, including a positive coefficient in the coal regression and a negative coefficient in the biofuel and waste regression. Both are significant at the five percent level. This shows that financial capital supports the transition to energy types with higher capital intensity; coal energy is more capital intensive than biomass energy in developing countries, where biomass energy predominately involves labor-intensive collection of fuelwood and other biomass.

The economic significance of the impact of private credit on coal share for lower-income countries is considerable. A one percentage point increase in private credit as a share of GDP is associated with an increase of 0.048 percentage points in the coal share, and a decrease of 0.051 percentage points for biofuel and waste, for lower-income countries. 
Table 5. Results, change in share of total primary energy supply for the ten years to 2013, high-income countries.

\begin{tabular}{|c|c|c|c|c|c|c|c|c|c|}
\hline & \multicolumn{9}{|c|}{ Dependent variables: Ten-year change in share of total primary energy supply } \\
\hline & $\begin{array}{r}\text { Biofuels } \\
\text { and waste }\end{array}$ & Hydro & Coal & Oil & $\begin{array}{r}\text { Natural } \\
\text { Gas }\end{array}$ & Nuclear & Wind & Solar & $\begin{array}{l}\text { Geo- } \\
\text { thermal }\end{array}$ \\
\hline \multirow{2}{*}{$\begin{array}{l}\text { Private credit, } \\
\text { divided by GDP }\end{array}$} & 0.003 & -0.011 & 0.004 & -0.052 & 0.020 & 0.015 & $0.013 * *$ & $0.006^{*}$ & $0.014 *$ \\
\hline & $(0.013)$ & $(0.008)$ & $(0.016)$ & $(0.032)$ & $(0.027)$ & $(0.038)$ & $(0.006)$ & $(0.003)$ & $(0.008)$ \\
\hline \multirow[t]{2}{*}{ Log GDP per capita } & -0.015 & 0.027 & -0.006 & -0.023 & 0.020 & 0.016 & 0.001 & 0.000 & $-0.016^{* * *}$ \\
\hline & $(0.021)$ & $(0.020)$ & $(0.012)$ & $(0.040)$ & $(0.034)$ & $(0.015)$ & $(0.004)$ & $(0.003)$ & $(0.006)$ \\
\hline \multirow{2}{*}{$\begin{array}{l}\text { Coal reserves, } \\
\text { KTOE per capita }\end{array}$} & -0.008 & 0.006 & $-0.022 * *$ & 0.030 & 0.011 & -0.015 & 0.002 & 0.001 & $-0.016^{* *}$ \\
\hline & $(0.015)$ & $(0.011)$ & $(0.010)$ & $(0.020)$ & $(0.027)$ & $(0.014)$ & $(0.002)$ & $(0.002)$ & $(0.007)$ \\
\hline \multirow{2}{*}{$\begin{array}{l}\text { Oil reserves, } \\
\text { KTOE per capita }\end{array}$} & -0.004 & 0.001 & $0.014 * *$ & -0.005 & -0.004 & -0.008 & 0.000 & $-0.001 * *$ & 0.003 \\
\hline & $(0.006)$ & $(0.003)$ & $(0.006)$ & $(0.012)$ & $(0.017)$ & $(0.005)$ & $(0.001)$ & $(0.001)$ & $(0.003)$ \\
\hline \multirow{2}{*}{$\begin{array}{l}\text { Gas reserves, } \\
\text { KTOE per capita }\end{array}$} & -0.000 & 0.001 & $0.006^{*}$ & -0.010 & 0.004 & -0.003 & 0.001 & 0.000 & -0.000 \\
\hline & $(0.003)$ & $(0.002)$ & $(0.003)$ & $(0.007)$ & $(0.008)$ & $(0.002)$ & $(0.001)$ & $(0.000)$ & $(0.001)$ \\
\hline \multirow{2}{*}{$\begin{array}{l}\text { Forest area, sq. km, } \\
\text { per capita }\end{array}$} & -0.226 & 0.231 & -0.326 & 0.263 & 0.385 & 0.798 & 0.002 & 0.025 & $-0.735^{* * *}$ \\
\hline & $(0.276)$ & $(0.175)$ & $(0.243)$ & $(0.482)$ & (0.607) & $(0.507)$ & $(0.051)$ & $(0.043)$ & (0.209) \\
\hline \multirow{2}{*}{$\begin{array}{l}\text { Land area, sq. km, } \\
\text { per capita }\end{array}$} & -0.070 & -0.055 & 0.090 & -0.110 & -0.064 & -0.028 & -0.021 & -0.019 & $0.264 * * *$ \\
\hline & $(0.074)$ & $(0.058)$ & $(0.064)$ & $(0.157)$ & $(0.142)$ & $(0.075)$ & $(0.014)$ & (0.017) & $(0.031)$ \\
\hline \multirow{2}{*}{$\begin{array}{l}\text { Temperature, }{ }^{\circ} \mathrm{C} \\
\text { ten-year average }\end{array}$} & -0.001 & -0.001 & -0.001 & -0.000 & 0.003 & 0.002 & -0.000 & $0.000 * *$ & $-0.001 * * *$ \\
\hline & $(0.001)$ & $(0.001)$ & $(0.001)$ & $(0.002)$ & (0.003) & $(0.002)$ & $(0.000)$ & $(0.000)$ & (0.000) \\
\hline \multirow{2}{*}{$\begin{array}{l}\text { Precipitation, meters } \\
\text { ten-year average }\end{array}$} & -0.007 & -0.001 & $0.023 * *$ & -0.008 & -0.007 & -0.013 & -0.001 & $-0.004 * * *$ & 0.012 \\
\hline & $(0.010)$ & $(0.005)$ & $(0.010)$ & $(0.023)$ & $(0.031)$ & (0.009) & $(0.002)$ & $(0.001)$ & (0.008) \\
\hline \multirow{2}{*}{$\begin{array}{l}\text { Initial energy use } \\
\text { per capita }\end{array}$} & 0.000 & -0.003 & $-0.006^{*}$ & 0.007 & 0.000 & 0.002 & -0.001 & -0.000 & $0.003^{*}$ \\
\hline & $(0.004)$ & $(0.003)$ & $(0.004)$ & $(0.010)$ & $(0.010)$ & $(0.003)$ & $(0.001)$ & $(0.001)$ & $(0.001)$ \\
\hline \multirow{2}{*}{$\begin{array}{l}\text { Change in total } \\
\text { energy use pc }\end{array}$} & -0.081 & 0.083 & 0.077 & -0.163 & 0.071 & 0.007 & 0.004 & 0.004 & -0.015 \\
\hline & $(0.071)$ & $(0.066)$ & $(0.048)$ & $(0.108)$ & $(0.131)$ & $(0.042)$ & $(0.012)$ & $(0.008)$ & (0.017) \\
\hline $\mathrm{R}^{2}$ & 0.358 & 0.275 & 0.235 & 0.329 & 0.244 & 0.072 & 0.361 & 0.430 & 0.561 \\
\hline
\end{tabular}

Notes: ***, **, * show statistical significance at 1,5 and 10 percent levels respectively. Robust standard errors are in brackets below the coefficients. 46 high-income

countries are included, but 45 for solar and coal. The independent variables are initial values from 2003, but coal reserves are for 2011. Temperature and precipitation are 10year averages to 2013. Initial energy use is total primary energy supply per capita in 2003 . Change in total energy use per capita is the five-year percentage change to 2003. 
Table 6. Results, change in share of total primary energy supply for the ten years to 2013, lower-income countries.

\begin{tabular}{|c|c|c|c|c|c|c|c|c|c|}
\hline & \multicolumn{9}{|c|}{ Dependent variables: Ten-year change in share of total primary energy supply } \\
\hline & $\begin{array}{r}\text { Biofuels } \\
\text { and waste }\end{array}$ & Hydro & Coal & Oil & $\begin{array}{r}\text { Natural } \\
\text { Gas }\end{array}$ & Nuclear & Wind & Solar & $\begin{array}{r}\text { Geo- } \\
\text { thermal }\end{array}$ \\
\hline $\begin{array}{l}\text { Private credit, } \\
\text { divided by GDP }\end{array}$ & $\begin{array}{r}-0.051 * * \\
(0.021)\end{array}$ & $\begin{array}{r}0.001 \\
(0.012)\end{array}$ & $\begin{array}{r}0.048 * * \\
(0.019)\end{array}$ & $\begin{array}{r}0.013 \\
(0.027)\end{array}$ & $\begin{array}{r}0.003 \\
(0.026)\end{array}$ & $\begin{array}{r}-0.004 \\
(0.007)\end{array}$ & $\begin{array}{l}-0.001 \\
(0.002)\end{array}$ & $\begin{array}{r}0.002 \\
(0.001)\end{array}$ & $\begin{array}{l}-0.005 \\
(0.006)\end{array}$ \\
\hline Log GDP per capita & $\begin{array}{r}0.007 \\
(0.008)\end{array}$ & $\begin{array}{l}-0.002 \\
(0.003)\end{array}$ & $\begin{array}{r}-0.010 \\
(0.008)\end{array}$ & $\begin{array}{r}-0.031 * * * \\
(0.012)\end{array}$ & $\begin{array}{r}0.033 * * * \\
(0.012)\end{array}$ & $\begin{array}{r}-0.001 \\
(0.002)\end{array}$ & $\begin{array}{r}0.001 \\
(0.000)\end{array}$ & $\begin{array}{r}0.000 \\
(0.000)\end{array}$ & $\begin{array}{r}0.002 \\
(0.003)\end{array}$ \\
\hline $\begin{array}{l}\text { Coal reserves, } \\
\text { KTOE per capita }\end{array}$ & $\begin{array}{r}-0.041 * * \\
(0.021)\end{array}$ & $\begin{array}{r}0.003 \\
(0.008)\end{array}$ & $\begin{array}{r}-0.055^{* * * *} \\
(0.019)\end{array}$ & $\begin{array}{r}0.011 \\
(0.029)\end{array}$ & $\begin{array}{r}0.096 * * \\
(0.044)\end{array}$ & $\begin{array}{r}-0.006 \\
(0.011)\end{array}$ & $\begin{array}{r}-0.002 \\
(0.002)\end{array}$ & $\begin{array}{r}-0.000 \\
(0.001)\end{array}$ & $\begin{array}{l}-0.001 \\
(0.004)\end{array}$ \\
\hline $\begin{array}{l}\text { Oil reserves, } \\
\text { KTOE per capita }\end{array}$ & $\begin{array}{r}-0.075^{*} \\
(0.044)\end{array}$ & $\begin{array}{r}0.020 \\
(0.022)\end{array}$ & $\begin{array}{r}0.039 \\
(0.044)\end{array}$ & $\begin{array}{r}0.079 \\
(0.077)\end{array}$ & $\begin{array}{r}0.031 \\
(0.082)\end{array}$ & $\begin{array}{r}-0.022 \\
(0.015)\end{array}$ & $\begin{array}{l}-0.002 \\
(0.003)\end{array}$ & $\begin{array}{r}0.001 \\
(0.002)\end{array}$ & $\begin{array}{r}0.001 \\
(0.010)\end{array}$ \\
\hline $\begin{array}{l}\text { Gas reserves, } \\
\text { KTOE per capita }\end{array}$ & $\begin{array}{r}0.042 \\
(0.104)\end{array}$ & $\begin{array}{r}-0.069 * * \\
(0.031)\end{array}$ & $\begin{array}{r}0.011 \\
(0.071)\end{array}$ & $\begin{array}{r}-0.008 \\
(0.168)\end{array}$ & $\begin{array}{r}0.111 \\
(0.179)\end{array}$ & $\begin{array}{r}0.002 \\
(0.022)\end{array}$ & $\begin{array}{r}-0.011 * * \\
(0.005)\end{array}$ & $\begin{array}{r}-0.011 * * \\
(0.004)\end{array}$ & $\begin{array}{l}-0.030 \\
(0.033)\end{array}$ \\
\hline $\begin{array}{l}\text { Forest area, sq. km, } \\
\text { per capita }\end{array}$ & $\begin{array}{l}-0.354 * \\
(0.186)\end{array}$ & $\begin{array}{r}0.009 \\
(0.071)\end{array}$ & $\begin{array}{r}-0.136 \\
(0.123)\end{array}$ & $\begin{array}{r}0.163 \\
(0.174)\end{array}$ & $\begin{array}{r}0.500 * * * \\
(0.189)\end{array}$ & $\begin{array}{r}0.018 \\
(0.024)\end{array}$ & $\begin{array}{r}-0.011 \\
(0.008)\end{array}$ & $\begin{array}{r}0.001 \\
(0.003)\end{array}$ & $\begin{array}{l}-0.086 \\
(0.071)\end{array}$ \\
\hline $\begin{array}{l}\text { Land area, sq. km, } \\
\text { per capita }\end{array}$ & $\begin{array}{r}-0.040 \\
(0.056)\end{array}$ & $\begin{array}{r}-0.071 * * \\
(0.029)\end{array}$ & $\begin{array}{r}0.015 \\
(0.045)\end{array}$ & $\begin{array}{l}0.166^{*} \\
(0.094)\end{array}$ & $\begin{array}{r}-0.227 * * * \\
(0.067)\end{array}$ & $\begin{array}{r}-0.006 \\
(0.008)\end{array}$ & $\begin{array}{r}-0.002 \\
(0.003)\end{array}$ & $\begin{array}{r}-0.002 \\
(0.002)\end{array}$ & $\begin{array}{r}0.016 \\
(0.017)\end{array}$ \\
\hline $\begin{array}{l}\text { Temperature, }{ }^{\circ} \mathrm{C} \\
\text { ten-year average }\end{array}$ & $\begin{array}{r}-0.001 \\
(0.001)\end{array}$ & $\begin{array}{l}0.001 * \\
(0.001)\end{array}$ & $\begin{array}{r}-0.001 \\
(0.001)\end{array}$ & $\begin{array}{r}-0.002 \\
(0.002)\end{array}$ & $\begin{array}{r}0.001 \\
(0.002)\end{array}$ & $\begin{array}{r}0.000 \\
(0.000)\end{array}$ & $\begin{array}{r}-0.000 \\
(0.000)\end{array}$ & $\begin{array}{l}-0.000 \\
(0.000)\end{array}$ & $\begin{array}{r}0.000 \\
(0.000)\end{array}$ \\
\hline $\begin{array}{l}\text { Precipitation, meters } \\
\text { ten-year average }\end{array}$ & $\begin{array}{r}0.003 \\
(0.010)\end{array}$ & $\begin{array}{l}-0.001 \\
(0.004)\end{array}$ & $\begin{array}{r}0.020 * * \\
(0.008)\end{array}$ & $\begin{array}{r}-0.009 \\
(0.011)\end{array}$ & $\begin{array}{r}-0.014 \\
(0.010)\end{array}$ & $\begin{array}{r}-0.000 \\
(0.001)\end{array}$ & $\begin{array}{r}0.000 \\
(0.001)\end{array}$ & $\begin{array}{r}-0.001 * * \\
(0.000)\end{array}$ & $\begin{array}{r}0.004 \\
(0.004)\end{array}$ \\
\hline $\begin{array}{l}\text { Initial energy use } \\
\text { per capita }\end{array}$ & $\begin{array}{r}0.030 * * * \\
(0.010)\end{array}$ & $\begin{array}{l}0.009 * \\
(0.005)\end{array}$ & $\begin{array}{r}0.000 \\
(0.016)\end{array}$ & $\begin{array}{r}-0.006 \\
(0.015)\end{array}$ & $\begin{array}{l}-0.042 * \\
(0.023)\end{array}$ & $\begin{array}{r}0.007 \\
(0.006)\end{array}$ & $\begin{array}{r}0.001 \\
(0.001)\end{array}$ & $\begin{array}{r}0.000 \\
(0.001)\end{array}$ & $\begin{array}{l}-0.001 \\
(0.002)\end{array}$ \\
\hline $\begin{array}{l}\text { Change in total } \\
\text { energy use pc }\end{array}$ & $\begin{array}{r}0.037 \\
(0.068)\end{array}$ & $\begin{array}{r}0.058 \\
(0.035)\end{array}$ & $\begin{array}{r}0.038 \\
(0.034)\end{array}$ & $\begin{array}{r}-0.185 * * * \\
(0.056)\end{array}$ & $\begin{array}{r}0.024 \\
(0.058)\end{array}$ & $\begin{array}{r}0.000 \\
(0.005)\end{array}$ & $\begin{array}{r}-0.000 \\
(0.002)\end{array}$ & $\begin{array}{r}0.002 \\
(0.002)\end{array}$ & $\begin{array}{r}0.026 \\
(0.021)\end{array}$ \\
\hline $\mathrm{R}^{2}$ & 0.190 & 0.287 & 0.283 & 0.406 & 0.199 & 0.094 & 0.121 & 0.318 & 0.075 \\
\hline
\end{tabular}

Notes: ***,**, * show statistical significance at 1, 5 and 10 percent levels respectively. Robust standard errors are in brackets below the coefficients. 69 low-income and middle-income countries, referred to as lower-income countries, are included. The independent variables are initial values from 2003 , except coal reserves, which are for 2011. Temperature and precipitation are 10-year averages to 2013. Initial energy use is total primary supply per capita in 2003. Change in total energy use per capita is the five-year percentage change to 2003. 
Fixed-effects panel estimates in Table 7 confirm the result that financial capital has been important for the transition to wind and solar energy. Using a panel of country data for 19982012, I find that bank credit to the private sector has a positive impact on wind energy, significant at the one percent level. This finding is similar to Brunnschweiler (2010) who finds a positive impact of private credit on renewable energy use for non-OECD countries for the period 1980-2006. Outstanding domestic private debt securities divided by GDP also has a positive association with wind energy consumption in Table 7 , again significant at the one percent level. Public debt, stock market capitalization, and international debt securities are not associated with greater wind energy use. Table 7 also provides evidence of finance contributing to the transition away from coal energy. This relates to high-income countries as the panel data are comprised primarily of high-income countries for which the financial system data used in Table 7 are more available.

The variables in Table 7 explain a large proportion of the variation in some of the energy shares, especially the 54 percent of variation explained for the wind share of total primary energy supply. ${ }^{13}$ In addition to the financial capital variables, some of the controls in Table 7 are also significant, indicating the importance of variables such as GDP per capita and climatic conditions. There is a positive and significant coefficient for the log of GDP per capita in explaining coal use in Table 7 . There is also a positive and significant coefficient for precipitation in contributing to hydro share of energy.

The amount of outstanding international private debt securities is strongly correlated with greater geothermal energy use. Endogeneity is a potential concern in this instance, as the use of large amounts of geothermal energy in a few countries may result in an increase in offshore borrowing from specialist debt suppliers. Specialist finance providers for energy types such as geothermal energy (NREL, 2011) deal with the specific combination of risk factors including geological risks. To reduce the reverse causation potential, I explored aggregating the private credit and debt variables, with this composite variable labelled as Private credit and debt in Table A3 in Appendix A. This composite variable does not have a significant coefficient for geothermal share, but there is significance at the five percent level for this composite variable in the wind regression, confirming an important role of financial capital for capital-intensive energy types such as wind.

\footnotetext{
${ }^{13}$ The coefficients and the $R$-squared are similar for the wind regression when using one-year lags, controlling for carbon dioxide emissions, and controlling for the oil price instead of the time dummies.
} 
Table 7. Results, fixed-effects panel estimates, 1998-2012.

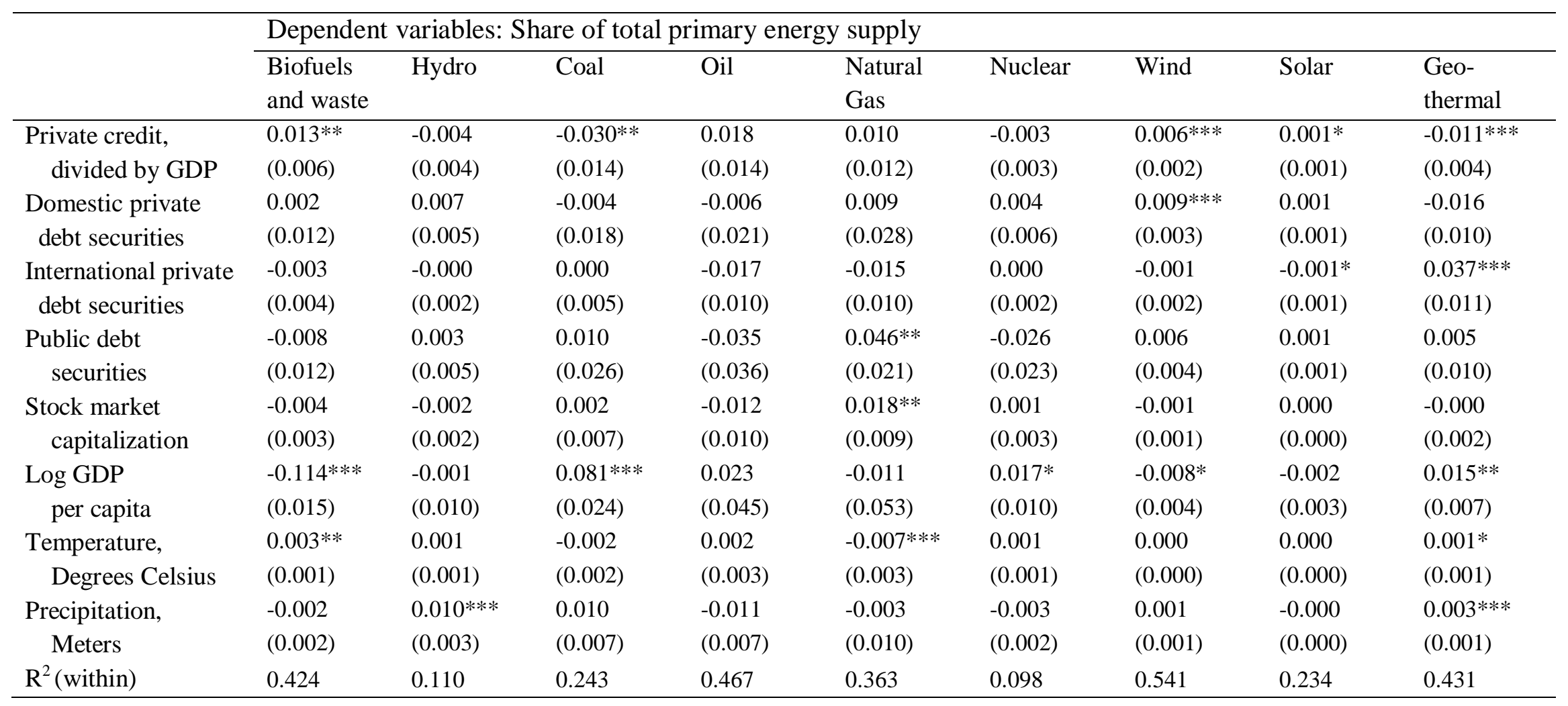

Notes: ***, **, * show statistical significance at 1,5 and 10 percent levels respectively. Robust standard errors clustered by country are in brackets below the coefficients. Coefficients for dummy variables for each year, and coefficients for constants, are not shown. All countries are included if data are available. There are 546 observations for solar and 551 observations for the other energy types. This includes 47 countries. All financial variables are divided by GDP. 


\section{Conclusion}

In this paper I find that financial capital has different impacts for different energy types depending on country development level, using data from 1998-2013 for up to 137 countries. For lower-income countries, financial capital contributes to the transition from biomass towards fossil fuels such as coal. For high-income countries, financial capital supports transitions away from fossil fuels and toward more capital-intensive wind energy. In both cases, financial capital appears to support transition to the next energy type on the nationallevel energy ladder (Burke, 2013). Financial capital impacts on energy transitions have subsequent implications for energy supply and security, and environmental implications for global climate change and local pollution levels.

For high-income countries, financial capital has been particularly important for capitalintensive energy types such as wind, and to a lesser degree solar. The structure of financial systems is also relevant for energy use: countries with larger pools of domestic credit and debt use more wind energy as a share of total energy, while other types of financial capital, such as public debt and equity, have not been strongly associated with wind energy expansion.

For lower-income countries, the impact of financial capital in contributing to the transition towards fossil fuels such as coal has a number of implications. If there is a continued increase in financial capital in lower-income countries, local air quality may deteriorate, with increased pollution from coal energy production, although pressure on deforestation to support biomass energy may reduce. At the global level, financial capital's contribution to greater coal use in lower-income countries may exacerbate potential climate change risks.

An implication of my results is that countries that experience growth in their financial sectors could also experience growth in energy types that are more capital-intensive than incumbent energy types. For the Netherlands, wind energy could grow considerably, given that private credit from banks divided by GDP increased by 52 percentage points in the decade to 2013 . Comparison of India and China is also relevant; increasing coal use could be more likely in India than in China given that private credit divided by GDP has increased by 20 percentage points in India in the decade to 2013, but by 11 percentage points in China.

Variation in financial sector size and growth could lead to different energy-mix paths, but financial capital is only one among many relevant variables affecting energy mix transitions. Other variables such as income and natural endowments are also important. For instance, 
hydro energy depends on precipitation and availability of water resources (see also Burke, 2010).

Financial policies that influence the size and structure of financial systems have potential to indirectly increase the use of energy types that are more capital intensive than incumbent energy types. This paper shows the importance of domestic private capital for energy transitions using data from 1998-2013, but other forms of capital could also play a role in different time periods. Greater use of international private capital could be supported by policy to reduce barriers to international finance. In addition, public capital could also potentially have a role in supporting new technologies that are perceived by private financial capital providers as too risky, before a track record of returns is established. Public capital could also be of greater importance in countries where state owned enterprises have a larger role in the energy sector.

\section{Acknowledgements}

I am grateful for comments received in anonymous peer review, and also from Paul Burke,

David Stern, Terence Wood, Alrick Campbell, participants at the Australian Agricultural and Resource Economics Society 2016 Annual Conference, participants at the 2016 Australian Conference of Economists, and participants in the Arndt-Corden Department of Economics Seminars.

\section{Appendix A}


Table A1. Results, change in electricity share, and capital intensity using IEA capital costs, for the ten years to 2013.

\begin{tabular}{|c|c|c|c|c|c|c|c|c|c|c|}
\hline & Dependent & iables: Ter & year change & electricity & hare, and te & ar change & capital int & sity & & \\
\hline & $\begin{array}{l}\text { Biofuels } \\
\text { and waste }\end{array}$ & Hydro & Coal & Oil & $\begin{array}{r}\text { Natural } \\
\text { Gas }\end{array}$ & Nuclear & Wind & Solar & $\begin{array}{l}\text { Geo- } \\
\text { thermal }\end{array}$ & $\begin{array}{r}\text { Capital } \\
\text { Intensity }\end{array}$ \\
\hline Private credit, & 0.005 & -0.004 & 0.008 & 0.013 & $-0.086^{* *}$ & 0.013 & $0.046 * *$ & 0.004 & 0.003 & $0.746 * * *$ \\
\hline divided by GDP & $(0.007)$ & $(0.019)$ & $(0.020)$ & $(0.028)$ & $(0.035)$ & $(0.037)$ & $(0.019)$ & $(0.003)$ & $(0.003)$ & $(0.243)$ \\
\hline Log GDP per capita & $0.006^{* * *}$ & 0.011 & -0.008 & -0.024 & 0.019 & -0.007 & 0.005 & $0.003 * *$ & $-0.005 * *$ & 0.053 \\
\hline & $(0.002)$ & $(0.017)$ & $(0.006)$ & $(0.017)$ & $(0.014)$ & $(0.009)$ & $(0.003)$ & $(0.001)$ & $(0.002)$ & $(0.068)$ \\
\hline Coal reserves, & -0.007 & 0.028 & -0.007 & 0.021 & -0.035 & 0.006 & -0.002 & $0.005^{*}$ & $-0.010 *$ & $0.222 *$ \\
\hline KTOE per capita & $(0.007)$ & $(0.023)$ & $(0.031)$ & $(0.027)$ & $(0.031)$ & $(0.017)$ & $(0.007)$ & $(0.003)$ & $(0.005)$ & $(0.117)$ \\
\hline Oil reserves, & -0.001 & 0.004 & $0.020 * * *$ & -0.015 & -0.008 & 0.003 & -0.001 & $-0.003 * * *$ & $-0.004 *$ & -0.086 \\
\hline KTOE per capita & $(0.003)$ & $(0.009)$ & $(0.006)$ & $(0.011)$ & $(0.014)$ & $(0.005)$ & $(0.003)$ & $(0.001)$ & $(0.002)$ & $(0.053)$ \\
\hline Gas reserves, & 0.000 & -0.000 & $0.003 * * *$ & $0.006^{* * *}$ & $-0.009 * * *$ & 0.000 & 0.000 & $-0.000 * *$ & -0.000 & 0.011 \\
\hline KTOE per capita & $(0.000)$ & $(0.001)$ & $(0.001)$ & $(0.002)$ & $(0.003)$ & $(0.001)$ & $(0.001)$ & $(0.000)$ & $(0.000)$ & $(0.010)$ \\
\hline Forest area, sq. km, & -0.068 & $-0.890 * *$ & $-0.665 * * *$ & 0.886 & 0.798 & 0.173 & -0.015 & 0.015 & -0.188 & -0.697 \\
\hline per capita & $(0.076)$ & $(0.451)$ & $(0.229)$ & $(0.555)$ & $(0.561)$ & $(0.173)$ & $(0.077)$ & $(0.022)$ & $(0.126)$ & $(1.588)$ \\
\hline Land area sq. $\mathrm{km}$, & -0.024 & -0.061 & $0.199 * *$ & -0.195 & 0.019 & 0.043 & $-0.058 * *$ & $-0.040 * * *$ & $0.079 *$ & $-1.568 * *$ \\
\hline per capita & $(0.022)$ & $(0.148)$ & $(0.078)$ & $(0.273)$ & $(0.281)$ & $(0.046)$ & $(0.026)$ & $(0.014)$ & $(0.045)$ & $(0.765)$ \\
\hline Temperature, ${ }^{\circ} \mathrm{C}$ & $-0.001 * * *$ & -0.002 & -0.001 & -0.001 & $0.004 * *$ & 0.001 & $-0.001 *$ & 0.000 & 0.000 & -0.007 \\
\hline ten-year average & $(0.000)$ & $(0.001)$ & $(0.001)$ & $(0.002)$ & $(0.002)$ & $(0.001)$ & $(0.000)$ & $(0.000)$ & $(0.000)$ & $(0.009)$ \\
\hline Precipitation, meters & 0.006 & 0.010 & $0.040 * * *$ & -0.021 & $-0.033^{*}$ & -0.004 & -0.002 & $-0.003 * * *$ & 0.002 & -0.083 \\
\hline ten-year average & $(0.004)$ & $(0.014)$ & $(0.010)$ & $(0.021)$ & $(0.020)$ & $(0.004)$ & $(0.005)$ & $(0.001)$ & $(0.003)$ & $(0.072)$ \\
\hline Initial electricity use & $-0.014 *$ & 0.008 & -0.039 & 0.031 & 0.023 & -0.000 & $-0.022 * *$ & -0.000 & $0.023 * *$ & -0.106 \\
\hline per capita & $(0.008)$ & $(0.042)$ & $(0.025)$ & $(0.036)$ & $(0.041)$ & $(0.015)$ & $(0.010)$ & $(0.003)$ & $(0.011)$ & $(0.172)$ \\
\hline Change in total & 0.001 & 0.020 & $0.009 * *$ & -0.011 & $-0.022 * *$ & 0.004 & $-0.005^{* *}$ & $0.004 * * *$ & 0.000 & $0.101 * * *$ \\
\hline electricity use pc & $(0.003)$ & $(0.021)$ & $(0.004)$ & $(0.025)$ & $(0.009)$ & $(0.004)$ & $(0.002)$ & $(0.001)$ & $(0.001)$ & $(0.038)$ \\
\hline $\mathrm{R}^{2}$ & 0.197 & 0.084 & 0.237 & 0.078 & 0.151 & 0.030 & 0.282 & 0.280 & 0.269 & 0.311 \\
\hline
\end{tabular}

Notes: ****** show statistical significance at 1,5 and 10 per cent levels respectively. Robust standard errors are in brackets below the coefficients. All countries are included if data are available. The sample covers 113 countries for coal and solar regressions and 114 for other types. The independent variables are initial values; they are for the year 2003 unless otherwise noted. Coal reserves are for 2011. Temperature and precipitation are 10-year averages to 2013. Initial electricity use is total electricity output per capita. Change in total electricity use per capita is a percentage change for the five years to 2003. Capital intensity is a measure calculated by the author as electricity-type capital intensity multiplied by electricity share, summed for each type of electricity. 
Table A2. Results, share of total primary energy supply in 2013

\begin{tabular}{|c|c|c|c|c|c|c|c|c|c|}
\hline & \multicolumn{9}{|c|}{ Dependent variables: Share of total primary energy supply } \\
\hline & $\begin{array}{r}\text { Biofuels } \\
\text { and waste }\end{array}$ & Hydro & Coal & Oil & $\begin{array}{r}\text { Natural } \\
\text { Gas }\end{array}$ & Nuclear & Wind & Solar & $\begin{array}{l}\text { Geo- } \\
\text { thermal }\end{array}$ \\
\hline $\begin{array}{l}\text { Private credit, } \\
\text { divided by GDP }\end{array}$ & $\begin{array}{l}0.080 * \\
(0.046)\end{array}$ & $\begin{array}{l}-0.022 \\
(0.023)\end{array}$ & $\begin{array}{r}0.037 \\
(0.057)\end{array}$ & $\begin{array}{r}0.066 \\
(0.059)\end{array}$ & $\begin{array}{r}-0.178 * * * \\
(0.062)\end{array}$ & $\begin{array}{l}-0.028 \\
(0.017)\end{array}$ & $\begin{array}{r}0.011 * * \\
(0.004)\end{array}$ & $\begin{array}{r}0.007 * * * \\
(0.003)\end{array}$ & $\begin{array}{r}0.018 \\
(0.019)\end{array}$ \\
\hline Log GDP per capita & $\begin{array}{r}-0.200^{* * * *} \\
(0.026)\end{array}$ & $\begin{array}{l}-0.013 \\
(0.014)\end{array}$ & $\begin{array}{r}0.015 \\
(0.017)\end{array}$ & $\begin{array}{r}0.131 * * * \\
(0.020)\end{array}$ & $\begin{array}{r}0.075 * * * \\
(0.025)\end{array}$ & $\begin{array}{r}0.007 \\
(0.006)\end{array}$ & $\begin{array}{r}0.002 * * \\
(0.001)\end{array}$ & $\begin{array}{r}0.001 * * \\
(0.001)\end{array}$ & $\begin{array}{l}-0.021 \\
(0.016)\end{array}$ \\
\hline $\begin{array}{l}\text { Coal reserves, } \\
\text { KTOE per capita }\end{array}$ & $\begin{array}{r}-0.062 * * \\
(0.031)\end{array}$ & $\begin{array}{l}-0.048 * \\
(0.026)\end{array}$ & $\begin{array}{r}0.226^{* * * *} \\
(0.050)\end{array}$ & $\begin{array}{r}-0.081 * * \\
(0.032)\end{array}$ & $\begin{array}{r}0.032 \\
(0.039)\end{array}$ & $\begin{array}{r}0.000 \\
(0.016)\end{array}$ & $\begin{array}{r}0.000 \\
(0.001)\end{array}$ & $\begin{array}{l}0.001^{*} \\
(0.001)\end{array}$ & $\begin{array}{r}-0.059 \\
(0.040)\end{array}$ \\
\hline $\begin{array}{l}\text { Oil reserves, } \\
\text { KTOE per capita }\end{array}$ & $\begin{array}{l}-0.030 \\
(0.022)\end{array}$ & $\begin{array}{r}0.012 \\
(0.015)\end{array}$ & $\begin{array}{r}0.004 \\
(0.017)\end{array}$ & $\begin{array}{r}0.049 * * \\
(0.020)\end{array}$ & $\begin{array}{r}-0.009 \\
(0.028)\end{array}$ & $\begin{array}{r}-0.021 * * \\
(0.008)\end{array}$ & $\begin{array}{l}-0.000 \\
(0.001)\end{array}$ & $\begin{array}{l}-0.001 * \\
(0.001)\end{array}$ & $\begin{array}{l}-0.006 \\
(0.011)\end{array}$ \\
\hline $\begin{array}{l}\text { Gas reserves, } \\
\text { KTOE per capita }\end{array}$ & $\begin{array}{r}-0.024 * * \\
(0.011)\end{array}$ & $\begin{array}{r}0.005 \\
(0.006)\end{array}$ & $\begin{array}{r}0.011 \\
(0.008)\end{array}$ & $\begin{array}{r}0.006 \\
(0.009)\end{array}$ & $\begin{array}{r}0.014 \\
(0.014)\end{array}$ & $\begin{array}{r}-0.010 * * \\
(0.004)\end{array}$ & $\begin{array}{r}0.001 \\
(0.000)\end{array}$ & $\begin{array}{r}0.000 \\
(0.000)\end{array}$ & $\begin{array}{r}-0.006 \\
(0.007)\end{array}$ \\
\hline $\begin{array}{l}\text { Forest area, sq. km, } \\
\text { per capita }\end{array}$ & $\begin{array}{r}3.103 * * * \\
(0.713)\end{array}$ & $\begin{array}{r}0.069 \\
(0.535)\end{array}$ & $\begin{array}{r}-0.567 \\
(0.364)\end{array}$ & $\begin{array}{l}-1.291 * \\
(0.660)\end{array}$ & $\begin{array}{r}0.049 \\
(0.768)\end{array}$ & $\begin{array}{r}0.367 \\
(0.232)\end{array}$ & $\begin{array}{r}0.005 \\
(0.015)\end{array}$ & $\begin{array}{r}0.013 \\
(0.012)\end{array}$ & $\begin{array}{r}-1.374 * \\
(0.816)\end{array}$ \\
\hline $\begin{array}{l}\text { Land area sq. km, } \\
\text { per capita }\end{array}$ & $\begin{array}{r}-0.507 * * * \\
(0.155)\end{array}$ & $\begin{array}{l}0.247 * \\
(0.132)\end{array}$ & $\begin{array}{r}-0.246 \\
(0.168)\end{array}$ & $\begin{array}{r}0.488 * * \\
(0.202)\end{array}$ & $\begin{array}{l}-0.439 * \\
(0.239)\end{array}$ & $\begin{array}{r}-0.257 * * \\
(0.100)\end{array}$ & $\begin{array}{r}-0.015 * * * \\
(0.006)\end{array}$ & $\begin{array}{r}-0.020 * * * \\
(0.007)\end{array}$ & $\begin{array}{l}0.616^{*} \\
(0.368)\end{array}$ \\
\hline $\begin{array}{l}\text { Temperature, }{ }^{\circ} \mathrm{C} \\
\text { ten-year average }\end{array}$ & $\begin{array}{r}0.008 * * \\
(0.003)\end{array}$ & $\begin{array}{l}-0.005^{*} \\
(0.003)\end{array}$ & $\begin{array}{r}-0.006 * * * \\
(0.002)\end{array}$ & $\begin{array}{r}0.007 * * \\
(0.003)\end{array}$ & $\begin{array}{r}0.001 \\
(0.003)\end{array}$ & $\begin{array}{r}-0.002 * * \\
(0.001)\end{array}$ & $\begin{array}{l}-0.000 \\
(0.000)\end{array}$ & $\begin{array}{l}0.000^{*} \\
(0.000)\end{array}$ & $\begin{array}{l}-0.002 \\
(0.001)\end{array}$ \\
\hline $\begin{array}{c}\text { Precipitation, meters } \\
\text { ten-year average }\end{array}$ & $\begin{array}{l}-0.004 \\
(0.025)\end{array}$ & $\begin{array}{r}0.028 * * \\
(0.012)\end{array}$ & $\begin{array}{r}0.005 \\
(0.016)\end{array}$ & $\begin{array}{l}-0.018 \\
(0.031)\end{array}$ & $\begin{array}{l}-0.035 \\
(0.034)\end{array}$ & $\begin{array}{r}-0.011 * * \\
(0.006)\end{array}$ & $\begin{array}{r}-0.001 \\
(0.001)\end{array}$ & $\begin{array}{r}-0.003 * * * \\
(0.001)\end{array}$ & $\begin{array}{r}0.040 * * * \\
(0.014)\end{array}$ \\
\hline $\begin{array}{l}\text { Initial energy use } \\
\text { per capita }\end{array}$ & $\begin{array}{r}0.041 * * * \\
(0.013)\end{array}$ & $\begin{array}{r}-0.003 \\
(0.007)\end{array}$ & $\begin{array}{l}-0.016^{*} \\
(0.008)\end{array}$ & $\begin{array}{r}-0.054 * * * \\
(0.011)\end{array}$ & $\begin{array}{r}0.016 \\
(0.017)\end{array}$ & $\begin{array}{r}0.011 * * \\
(0.005)\end{array}$ & $\begin{array}{r}-0.001 * \\
(0.000)\end{array}$ & $\begin{array}{l}-0.001 * \\
(0.000)\end{array}$ & $\begin{array}{r}0.011 \\
(0.011)\end{array}$ \\
\hline $\begin{array}{l}\text { Change in total } \\
\text { energy use pc }\end{array}$ & $\begin{array}{l}-0.187 \\
(0.131)\end{array}$ & $\begin{array}{l}-0.160 \\
(0.177)\end{array}$ & $\begin{array}{r}0.041 \\
(0.136)\end{array}$ & $\begin{array}{r}-0.053 \\
(0.154)\end{array}$ & $\begin{array}{r}0.258 \\
(0.205)\end{array}$ & $\begin{array}{l}-0.050 \\
(0.040)\end{array}$ & $\begin{array}{r}-0.005 \\
(0.004)\end{array}$ & $\begin{array}{r}-0.001 \\
(0.004)\end{array}$ & $\begin{array}{r}0.019 \\
(0.052)\end{array}$ \\
\hline $\mathrm{R}^{2}$ & 0.612 & 0.135 & 0.289 & 0.418 & 0.359 & 0.262 & 0.339 & 0.318 & 0.339 \\
\hline
\end{tabular}

Notes: ***,**, * show statistical significance at 1, 5 and 10 per cent levels respectively. Robust standard errors are in brackets below the coefficients. All countries are included if data are available. The sample covers 114 countries for coal and 115 for other types. The independent variables are for the year 2003 unless otherwise noted. Coal reserves are for 2011. Temperature and precipitation are 10-year averages to 2013. Initial energy use is total primary energy supply per capita in 2003. Change in total energy use per capita is a percentage change for the five years to 2003 . 
Table A3. Results, fixed-effects panel estimates, combined private credit and debt variable, 1998-2012.

\begin{tabular}{|c|c|c|c|c|c|c|c|c|c|}
\hline & \multicolumn{9}{|c|}{ Dependent variables: Share of total primary energy supply } \\
\hline & $\begin{array}{l}\text { Biofuels, } \\
\text { waste }\end{array}$ & Hydro & Coal & Oil & $\begin{array}{l}\text { Natural } \\
\text { Gas }\end{array}$ & Nuclear & Wind & Solar & $\begin{array}{l}\text { Geo- } \\
\text { thermal }\end{array}$ \\
\hline $\begin{array}{l}\text { Private credit and debt, } \\
\text { divided by GDP }\end{array}$ & $\begin{array}{l}0.004 \\
(0.003)\end{array}$ & $\begin{array}{l}-0.001 \\
(0.001)\end{array}$ & $\begin{array}{l}-0.012 * * \\
(0.005)\end{array}$ & $\begin{array}{l}-0.001 \\
(0.005)\end{array}$ & $\begin{array}{l}-0.001 \\
(0.007)\end{array}$ & $\begin{array}{l}-0.000 \\
(0.001)\end{array}$ & $\begin{array}{l}0.003 * * \\
(0.002)\end{array}$ & $\begin{array}{l}0.000 \\
(0.000)\end{array}$ & $\begin{array}{l}0.009 \\
(0.007)\end{array}$ \\
\hline $\begin{array}{l}\text { Public debt, } \\
\text { divided by GDP }\end{array}$ & $\begin{array}{l}-0.017 \\
(0.010)\end{array}$ & $\begin{array}{l}0.007^{*} \\
(0.004)\end{array}$ & $\begin{array}{l}0.027 \\
(0.021)\end{array}$ & $\begin{array}{l}-0.053 \\
(0.032)\end{array}$ & $\begin{array}{l}0.035^{*} \\
(0.020)\end{array}$ & $\begin{array}{l}-0.024 \\
(0.022)\end{array}$ & $\begin{array}{l}0.003 \\
(0.004)\end{array}$ & $\begin{array}{l}0.000 \\
(0.001)\end{array}$ & $\begin{array}{l}0.024 \\
(0.022)\end{array}$ \\
\hline $\begin{array}{l}\text { Stock market capitalization, } \\
\text { divided by GDP }\end{array}$ & $\begin{array}{l}-0.003 \\
(0.003)\end{array}$ & $\begin{array}{l}-0.001 \\
(0.002)\end{array}$ & $\begin{array}{l}0.001 \\
(0.006)\end{array}$ & $\begin{array}{l}-0.010 \\
(0.011)\end{array}$ & $\begin{array}{l}0.020 * * \\
(0.009)\end{array}$ & $\begin{array}{l}0.001 \\
(0.003)\end{array}$ & $\begin{array}{l}-0.000 \\
(0.001)\end{array}$ & $\begin{array}{l}0.000 \\
(0.000)\end{array}$ & $\begin{array}{l}-0.005 \\
(0.005)\end{array}$ \\
\hline Log GDP per capita & $\begin{array}{l}-0.115^{* * *} \\
(0.015)\end{array}$ & $\begin{array}{l}0.001 \\
(0.009)\end{array}$ & $\begin{array}{l}0.084 * * * \\
(0.023)\end{array}$ & $\begin{array}{l}0.020 \\
(0.044)\end{array}$ & $\begin{array}{l}-0.010 \\
(0.050)\end{array}$ & $\begin{array}{l}0.018^{*} \\
(0.010)\end{array}$ & $\begin{array}{l}-0.007 \\
(0.005)\end{array}$ & $\begin{array}{l}-0.002 \\
(0.003)\end{array}$ & $\begin{array}{l}0.012 \\
(0.012)\end{array}$ \\
\hline $\begin{array}{l}\text { Temperature, } \\
\text { Degrees Celsius }\end{array}$ & $\begin{array}{l}0.003 * * \\
(0.001)\end{array}$ & $\begin{array}{l}0.001 \\
(0.001)\end{array}$ & $\begin{array}{l}-0.002 \\
(0.002)\end{array}$ & $\begin{array}{l}0.002 \\
(0.003)\end{array}$ & $\begin{array}{l}-0.007 * * * \\
(0.003)\end{array}$ & $\begin{array}{l}0.001 \\
(0.001)\end{array}$ & $\begin{array}{l}0.000 \\
(0.000)\end{array}$ & $\begin{array}{l}0.000 \\
(0.000)\end{array}$ & $\begin{array}{l}0.001 \\
(0.001)\end{array}$ \\
\hline Precipitation, meters & $\begin{array}{l}-0.002 \\
(0.002)\end{array}$ & $\begin{array}{l}0.010 * * * \\
(0.003)\end{array}$ & $\begin{array}{l}0.010 \\
(0.007)\end{array}$ & $\begin{array}{l}-0.011 \\
(0.007)\end{array}$ & $\begin{array}{l}-0.003 \\
(0.010)\end{array}$ & $\begin{array}{l}-0.003 \\
(0.002)\end{array}$ & $\begin{array}{l}0.001 \\
(0.001)\end{array}$ & $\begin{array}{l}-0.000 \\
(0.000)\end{array}$ & $\begin{array}{l}0.002 \\
(0.001)\end{array}$ \\
\hline
\end{tabular}

Notes: ***,**, * show statistical significance at 1,5 and 10 per cent levels respectively. Robust standard errors clustered by country are in brackets below the coefficients.

Coefficients for dummy variables for each year, and coefficients for constants, are not shown. All countries are included if data are available. There are 546 observations for solar and 551 observations for the other energy types. This includes 47 countries. 


\section{References}

Ayyagari, M., Demirgüç-Kunt, A., Maksimovic, V., 2011. Firm innovation in emerging markets: The role of finance, governance, and competition. Journal of Financial and Quantitative Analysis 46 (6), 1545-1580.

BP, 2015. Statistical Review of World Energy. London: British Petroleum.

Brunnschweiler, C.N., 2010. Finance for renewable energy: an empirical analysis of developing and transition economies. Environment and Development Economics 15, 241274.

Burke, P.J., 2010. Income, resources, and electricity mix. Energy Economics 32, 616-626.

Burke, P.J., 2013. The national-level energy ladder and its carbon implications. Environment and Development Economics 18 (4), 484-503.

Čihák, M., Demirgüç-Kunt, A., Feyen, E., Levine, R., 2012. Benchmarking Financial Systems around the World. World Bank Policy Research Working Paper 6175, World Bank, Washington, D.C.

Citi, 2015. Energy Darwinism II: Why a Low Carbon Future Doesn't Have to Cost the Earth. Citi GPS: Global Perspectives and Solutions, August 2015.

Corsatea, T.D., Giaccaria, S., Arantegui, R.L., 2014. The role of sources of finance on the development of wind technology. Renewable Energy 66, 140-149.

ESMAP (Energy Sector Management Assistance Program. The World Bank Group), 2012.

Geothermal Handbook: Planning and Financing Power Generation. Technical Report 002/12, Washington DC.

Gao, Y-X., Liao, H., Burke, P.J., Wei, Y-M., 2015. Road transport energy consumption in the G7 and BRICS: 1973-2010. International Journal of Global Energy Issues 38 (4/5/6), 342356.

GFDD (Global Financial Development Database), 2015. The World Bank <http://data.worldbank.org/data-catalog/global-financial-development> (accessed 15 September 2015).

Harris, I., Jones, P.D., Osborn, T.J., Lister, D.H., 2014. Updated high-resolution grids of monthly climatic observations - the CRU TS3.10 Dataset. International Journal of Climatology 34, 623-642.

Helm, D., 2012. The Carbon Crunch: How We're Getting Climate Change Wrong - and How to Fix It. Yale University Press, New Haven and London.

IEA (International Energy Agency), 2012. Technology Roadmap: Fuel Economy of Road Vehicles. IEA: Paris.

IEA (International Energy Agency), 2014. World Energy Investment Outlook: Special Report. IEA: Paris.

IEA (International Energy Agency), 2015. IEA World Energy Statistics and Balances. IEA, Paris. 
Kumar, S., Fujii, H., Managi, S., 2015. Substitute or complement? Assessing renewable and non-renewable energy in OECD countries. Applied Economics 47(14), 1438-1459.

Levine, R., 2005. Finance and Growth: Theory and Evidence, in: Aghion, P., Durlauf, S. (Eds.), Handbook of Economic Growth, chapter 12, 865-934.

NREL (National Renewable Energy Laboratory), 2011. Guidebook to Geothermal Power Finance', Subcontract Report NREL/SR-6A20-49391. Salmon, J.P., Meurice, J., Wobus, N., Stern, F., Duaime, M., Navigant Consulting, Boulder Colorado, March 2011.

Obstfeld, M., Rogoff, K., 2001. The six major puzzles in international macroeconomics: is there a common cause, in: Bernanke, B., Rogoff, K. (Eds.) NBER macroeconomics annual 2000. Cambridge MA: MIT Press, 339-412.

OECD (Organisation for Economic Co-operation and Development), 2015. Mapping Channels to Mobilise Institutional Investment in Sustainable Energy. Green Finance and Investment, OECD Publishing, Paris.

Ondraczek, J., Komendantova, N., Patt, A., 2015. WACC the dog: The effect of financing costs on the levelized cost of solar PV power. Renewable Energy 75, 888-898.

Painuly, J.P., Wohlgemuth, N., 2006. Renewable energy financing - what can we learn from experience in developing countries? Energy Studies Review 14 (2), 154-170.

Pfeiffer, B., Mulder, P., 2013. Explaining the diffusion of renewable energy technology in developing countries. Energy Economics 40, 285-296.

Popp, D., Hascic, I., Medhi N., 2011. Technology and diffusion of renewable energy. Energy Economics 33, 648-662.

Power Generation Costs Analysis Working Group, 2015. Report on analysis of generation costs, etc. for subcommittee on long-term energy supply-demand outlook, May 2015, Ministry of Economy, Trade and Industry, Japan. <http://www.meti.go.jp/english/press/2015/pdf/0716_01b.pdf> (accessed 16 September 2016)

Rajan, R.G., Zingales, L., 1998. Financial dependence and growth. American Economic Review 88 (3), 559-586.

Sadorsky, P., 2010. The impact of financial development on energy consumption in emerging economies. Energy Policy 38, 2528-2535.

Sadorsky, P., 2011. Financial development and energy consumption in Central and Eastern European frontier economies. Energy Policy 39, 999-1006.

Stern, D.I., 2011. The role of energy in economic growth. Annals of the New York Academy of Sciences 1219, 26-51.

Timmons, D., Harris, J.M., Roach, B., 2014. The Economics of Renewable Energy. Global Development and Environment Institute Tufts University, Medford, MA

Tirpak, D., Adams, H., 2008. Bilateral and multilateral financial assistance for the energy sector of developing countries. Climate Policy 8 (2), 135-151.

US EIA (United States. Energy Information Administration), 2015a. Capital Cost for Electricity Plants. < http://www.eia.gov/forecasts/capitalcost/> (accessed 22 February 2016). 
US EIA (United States Energy Information Administration), 2015b. Annual Energy Outlook 2015. < http://www.eia.gov/forecasts/aeo/electricity_generation.cfm> (accessed 22 February 2016).

US EIA (United States Energy Information Administration), 2015c. International Energy Statistics. U.S. Energy Information Statistics. < http://www.eia.gov/cfapps/ipdbproject/iedindex3.cfm?tid=5\&pid=53\&aid=1> $($ accessed 20 October 2015).

Warren, G.J., 2010. Equity home bias in Australian superannuation funds. Australian Journal of Management 35 (1), 69-93.

World Bank, 2016. World Development Indicators, 1998-2012. World Bank. http://data.worldbank.org/ (accessed 28 February 2016).

Zhao, Y., Tang, K.K., Wang, L., 2013. Do renewable electricity policies promote renewable electricity generation? Evidence from panel data. Energy Policy 62, 887-897. 